\title{
Pulmonary immune cells in health and disease: the eosinophil leucocyte (Part I)
}

\author{
C. Kroegel*, J-C. Virchow Jr*, W. Luttmann*, C. Walker* J.A. Warner**
}

\begin{abstract}
Pulmonary immune cells in health and disease: the eosinophil leucocyte (Part I). C. Kroegel, J-C. Virchow Jr, W. Luttmann, C. Walker, J.A. Warner. CERS Journals Ltd 1994.

ABSTRACT: Increasing evidence has accumulated to suggest that eosinophils play a key role in the pathogenesis of asthma and other pulmonary diseases by damaging infiltrated bronchial tissue and lung parenchyma.

The first part of this review on eosinophils describes the cellular characteristics and properties of the cell, which help in understanding its role in disease. The article focuses on origin, maturation and differentiation of the eosinophil, its morphological and phenotypical properties, as well as its preformed and newly generated mediators of inflammation. The cause and putative significance of eosinophil heterogeneity in respect to function and density will also be discussed. In addition, the naturally occurring mediators through which eosinophils are activated and communicate with other inflammatory cells are outlined.

The first part closes with new aspects of eosinophil recruitment from the circulation into perivascular tissue, including nonselective and putative selective adhesion mechanisms and chemotaxis.

Eur Respir J., 1994, 7, 519-543.
\end{abstract}

\begin{abstract}
*Dept of Pneumology, Medical Clinics, Albert-Ludwigs-University, Freiburg i.Br., Germany. **Dept of Physiology and Pharmacology, University of Southampton, UK.

Correspondence: C. Kroegel, Dept of Pneumology, Medical Clinics, University of Freiburg, Hugstetter Str. 55, D-79106 Freiburg i.Br, Germany.
\end{abstract}

Keywords: Blood and bronchoalveolar, eosinophils, eosinophil phenotype, granular proteins, hypodense eosinophil, mechanism of tissue infiltration

Received: November 301993

Accepted after revision December 101993

This work was supported by the State Baden-Württemberg, Kernforschungszentrum Karlsruhe, Germany (PUGL93001).
Over the past $10 \mathrm{yrs}$, our understanding of the cellular biology, function and pathophysiological role of the eosinophil leucocyte in disease has undergone profound changes. From being widely considered as a modulator of inflammation, the eosinophil is now being regarded as an effector cell in inflammation, which exerts a range of cytotoxic effects on various cells and tissues. It is not only associated with host defence mechanisms in parasitic infestation but is also implicated in the pathogenesis of allergic, immunological and malignant disorders, as well as diseases of unknown origin.

While much still remains to be elucidated about the mechanism of eosinophil-associated inflammation, research in recent years has led to a much better understanding of the possible mechanisms underlying eosinophil activation, recruitment, and the potential role of mediators, such as platelet-activating factor (PAF) and the pluripotent actions of cytokines on this cell. The purpose of this article is to review current knowledge of the biology and immunology of eosinophils with respect to their pathophysiological role in pulmonary disease.

\section{Origin and differentiation}

Eosinophils originate from bone marrow precursor cells and differentiate under the control of a number of growth or colony-stimulating factors derived from T-lymphocytes and mesenchymal cells. Three cytokines, granulocyte/ macrophage colony-stimulating factor (GM-CSF), interleukin-3 (IL-3) and interleukin-5 (IL-5) are currently recognized in promoting eosinophilopoiesis [1]. Following a differentiation and maturation period of approximately 5 days, the mature eosinophil leaves the marrow and circulates in the peripheral blood with an estimated halflife of 13-18 h (mean blood transient time $25 \mathrm{~h}$ ) before migrating into the tissue. Eosinophils are distributed in various organs but prefer tissues that interface with an external environment, such as the gastrointestinal, lower genitourinary and respiratory tracts [2]. Although there is a paucity of data on the longevity of the cells, eosinophils, sequestered in tissues, are likely to persist for at least 6 days. However, the life-span of tissue eosinophils may be extended by the effect of systemically and locally released cytokines, such as IL-5 and GM-CSF [3, 4].

\section{Morphology}

The most distinguishing morphological features of the eosinophil are a bilobed nucleus and large eosinophilic granules, which stain yellow-pink with eosin and other acid aniline dyes [5]. These elliptical secondary or specific granules possess an electron-dense crystalloid core, that is embedded in a less electron-dense matrix (fig. 1). They appear after the myelocyte stage and may develop from large spherical primary lysosomal granules [6]. Some of these primary granules are thought to develop into 

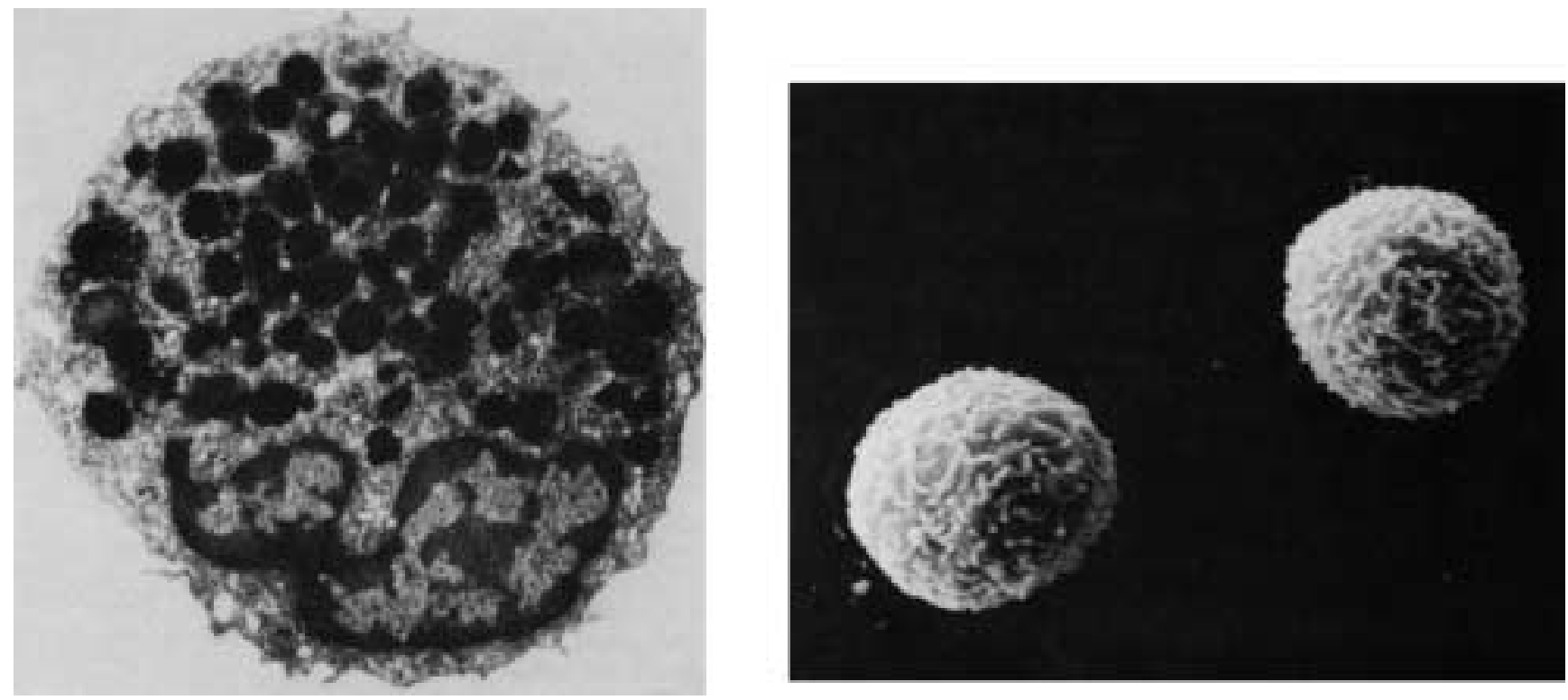

Fig. 1. - a) Transmission; and b) scanning electron micrographs of resting human eosinophil leucocytes obtained from the blood.

smaller homogeneous dense cytoplasmic bodies containing lysophosphatase [7,8], which crystallize in vivo and in vitro to form the distinctive bipyramidal Charcot-Leyden crystals $[9,10]$. A third type of granule, the so called small granules, are less conspicuous. They form during the metamyelocyte stage, and increase progressively in number with cellular maturation to become small and less electron-dense homogeneous cytoplasmic structures [11]. All three granules are present in the mature eosinophil [7,8] (fig. 2), and all contain different constituents (table 1).

Eosinophils also show smooth, elongated, rounded, Cshaped or circular-shaped membrane-bound cytoplasmic structures, that are generally empty but are thought to play a role in the extrusion processes of the cell. They were previously referred to as microgranules [12], but are best identified as vesiculotubular structures [13, 14]. They can be differentiated from the small granules by the lack of a less-electon dense outer matrix.

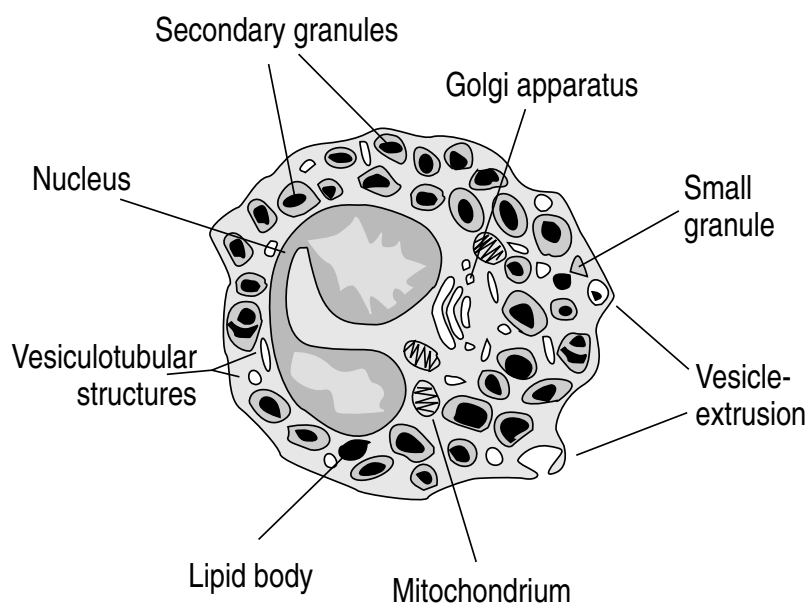

Fig. 2. - Morphology and characteristic organelles of the human eosinophil leucocyte.

Table 1. - Distinct cytoplasmic structures of the human eosinophil leucocyte

\begin{tabular}{lll}
\hline Spherical cyloplasmic structure & Appearance during differentiation & \multicolumn{1}{c}{ Constituents/function } \\
\hline Primary granule & $\begin{array}{l}\text { Immature eosinophil leucocyte } \\
\text { (promyelocyte) }\end{array}$ & Lysophosphatase \\
$\begin{array}{l}\text { Secondary granule } \\
\text { ("specific" granule) }\end{array}$ & Mature eosinophil leucocyte & $\begin{array}{l}\text { Basic proteins (MBP, ECP, EPX), } \\
\text { hydrolases (collagenase, } \beta \text {-glucuronidase) } \\
\text { eosinophil peroxidase }\end{array}$ \\
$\begin{array}{l}\text { Small granule } \\
\begin{array}{l}\text { Microgranules } \\
\text { (vesiculotubular-structures) }\end{array}\end{array}$ & $\begin{array}{l}\text { Mature eosinophil leucocyte } \\
\text { Lipid bodies }\end{array}$ & $\begin{array}{l}\text { Arylsulphatase B, acid phosphatase } \\
\text { Transport system }\end{array}$ \\
\hline
\end{tabular}

MBP: major basic protein; ECP: eosinophil cationic protein; EPX: eosinophil protein X. 
Other prominent organelles in eosinophils are lipid bodies [15], which have also been identified in a wide variety of mammalian cells. Lipid bodies are round osmophilic, non-membrane-bound structures and often larger than specific granules. Their numbers increase during activation of eosinophils, and they appear to serve as intracellular sites of arachidonic acid storage and metabolism $[15,16]$, though their full function has not yet been delineated. Eosinophils also contain ubiquitous organelles, such as the rough endoplasmatic reticulum, free ribosomes, a small Golgi apparatus and mitochondria. The latter two seem to become more prominent in activated cells [17] (fig. 2).

\section{Membrane receptors and surface markers}

In recent years, a number of cell surface receptors and proteins have been identified on human eosinophils, which can be divided into binding sites for immunoglobulins, lipid mediators, complement proteins, cytokines and adhesion molecules [18]. A summary of the receptors currently recognized is given in figure 3 .

Eosinophil leucocytes share many antigens found on other circulating white blood cells, such as the class I human leucocyte antigen (HLA) and the common leucocyte antigen CD45 [19, 20]. Although a specific epitope has not yet been identified, eosinophils can be differentiated from other leucocytes because they lack certain antigenic determinants. It is of particular significance that native eosinophils do not express the immunoglobulin $\mathrm{G}$ ( $\mathrm{IgG})$ receptor Fc $\gamma$ RIII (CD16), an observation which is currently used to distinguish between eosinophil and neutrophil populations [21]. In addition, unlike monocytes, which express Fc $\gamma R$ I and Fc $\gamma$ RII, and neutrophils, which express Fc $\gamma$ RII and Fc $\gamma$ RIII, eosinophils bear only the Fc $\gamma$ RII receptor (CDw32) on their membrane surface [20, 22]. However, a recent report has demonstrated that eosinophils cultured in the presence of interferon- $\gamma$ (IFN- $\gamma$ ) induce both Fc $\gamma$ RI (CD64) and Fc $\gamma$ RIII (CD16) [23]. In addition, whereas freshly isolated blood eosinophils respond poorly when challenged with anti-IgG and secreted only eosinophil cationic protein (ECP) [24, 25], INF- $\gamma$ exposed eosinophils responded to anti-CD16 antibodies with a significant release of leukotriene $\mathrm{C}_{4}\left(\mathrm{LTC}_{4}\right)$ [23].

Immunoglobulin $\mathrm{E}(\mathrm{IgE})$ receptors on human eosinophils have been demonstrated by the rosette technique (using IgE myeloma protein bound to red cells), as well as by radioligand studies using ${ }^{125} \mathrm{I}$-labelled $\mathrm{IgE}$ [26-28]. This receptor appears to be similar, but not completely identical, to the FceRII (CD23) low-affinity receptors on lymphocytes, monocytes and other cells [28], since the CD23 antibody does not bind to the cells. There appear to be increased numbers of FceRII receptors on hypodense and normodense eosinophils from patients with eosinophilia, when compared to eosinophils from normal subjects [29]. Functionally, binding of IgE leads to the release of eosinophil peroxidase (EPO) [30] and

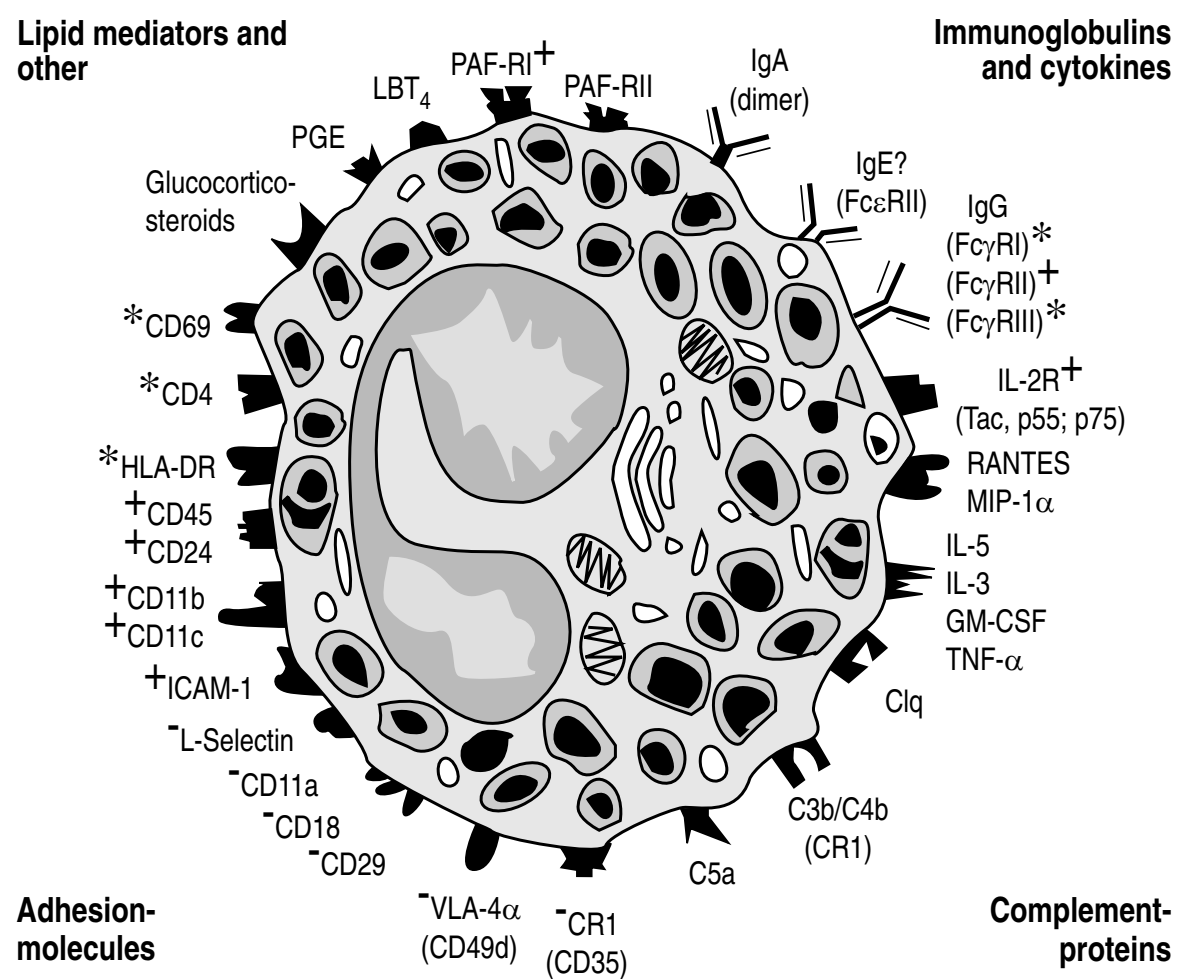

Fig. 3. - Schematic representation of surface antigens identified on eosinophils. Some of the antigens are upregulated (+), downregulated $(-)$ or induced $(*)$ following recruitment from the circulation into tissue. The existence of an IgE receptor on eosinophils is still a matter of ongoing debate (?). CD: cluster differentiation; CR: complement receptor; FcyR: IgE-receptor; IgG-receptor; GM-CSF: granulocyte/macrophage colony-stimulating factor;

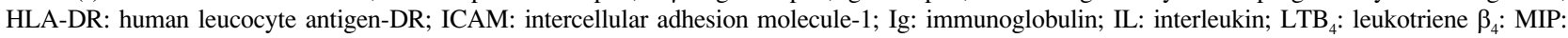
macrophage inflammatory protein; PAF: platelet-activating factor; PAF-RI: high-affinity PAF receptor; PAF-RII: low-affinity PAF receptor; PGE: prostaglandin E; RANTES: regulated upon activation in normal T-cells expressed and secreted; TNF: tumour necrosis factor; VLA: very late activation antigen. (Modified after KROEGEL et al. [18] 1992). 
generation of platelet activating factor (PAF) [24], but fails to secrete ECP.

The same group [30] reported that human and animal eosinophils bind monomeric or secretory immunoglobulin A $(\operatorname{Ig} \mathrm{A})$, though with a relatively low affinity. Only recently, the expression of Fc $\alpha \mathrm{R}$ on eosinophils was confirmed using immunofluorescence analysis of blood eosinophils from normal and allergic individuals [31]. Although neutrophils expressed much higher levels of FcoR than eosinophils in normal blood, eosinophils obtained from allergic subjects displayed enhanced Fc $\alpha \mathrm{R}$ expression, whereas neutrophils did not. Challenge of eosinophils with IgA and particularly the IgA-dimer causes significant degranulation, including the release of EPO [25, 30] and ECP [32].

Normal blood eosinophils do not express immunoglobulin $M(\operatorname{IgM})$ receptors $[29,33,34]$, although $\operatorname{IgM}$ binding to eosinophils can be induced by culturing them in the presence of cytokines [34]. The potential functional effects of $\operatorname{IgM}$ binding to eosinophils are as yet not known.

In addition to immunoglobulin receptors, a number of adhesion molecules have been detected on eosinophils, including the $\beta_{1}$-integrin very late activation antigen (VLA) (CD29, CDw49), the $\beta_{2}$-integrins CD11a, CD11b (CR3), CD11c and their common $\beta$-chain CD18, the immunoglobulin superfamily (intercellular adhesion molecule-1 (ICAM)-1, CD16, CD31, CD32, CD58), as well as selectins, the major histocompatibilty antigen HLA-DR, CD4, CD69 and interleukin-2R (IL-2R) [19, 35-44]. Some of these surface antigens are expressed only on activated eosinophils (see below). The leucocyte integrins facilitate the intercellular adhesion of eosinophils to microvascular endothelium [45-47], and are essentially involved in the recruitment and migration of the cell into inflamed tissue (see below). They may also be involved in binding of other ligands, such as opsonized targets [48-52] and modifying other basic cellular functions.

Both eosinophil precursors and mature cells express the cell surface glycoprotein CD4 [53, 54], which has originally been known to be present on T-helper lymphocytes and on leucocytes of the monocyte/macrophage lineage. The CD4 binds human immunodeficiency virus-1 (HIV-1) gp 120 and can act as a signal transducer to elicit eosinophil migration [55]. Employing interleukin5 (IL-5) stimulated bone marrow cultures, it has been shown that HIV-1 can infect eosinophil precursor cells in vitro [54], suggesting that eosinophils may serve as a reservoir for the virus in vivo.

Receptors for the complement factors C1q, C3a, C3b/C4b (CRI), iC3b (CR3), C3d and C5a have also been identified on human eosinophils [19, 56-59]. However, eosinophils have far fewer of these receptors than neutrophils and both the structure and affinity of the C5a receptor differs from that of the C5a receptor on neutrophils [60]. The proportion of complement bearing eosinophils ranges from $30 \%$ in normal individuals to $40 \%$ in patients with parasitic infestations [33]. The chemotactic peptide Nformyl-methionyl-leucyl-phenylalanine (fMLP) enhances the number of $\mathrm{C} 3 \mathrm{~b}$ receptors [61]. In addition, ECF-A, histamine and its major catabolite, imidazole acetic acid, have been reported to increase the expression of $\mathrm{C} 3 \mathrm{~b}$ and
C4 receptors on human eosinophils, whereas $\mathrm{C} 3 \mathrm{~d}$ and $\mathrm{IgG}(\mathrm{Fc} \gamma)$ receptors remained unaffected [56].

As mentioned above, eosinophils express receptors for iC $3 b$ (CR3), a degradation product of C3b. Functionally, CR3 appears to be similar to the receptor for $\mathrm{C} 3 \mathrm{~b}$, causing binding of particles coated with $\mathrm{iC} 3 \mathrm{~b}$ to a phagocytic cell surface but failing to trigger ingestion in the absence of a second signal [62].

Eosinophils express a number of receptors for lipid mediators, including prostaglandin E (PGE), leukotriene $\mathrm{B}_{4}\left(\mathrm{LTB}_{4}\right)$, and PAF. PAF represents one of the most potent naturally occurring stimuli for eosinophils, inducing not only chemokinesis and chemotaxis but also release of granular proteins, production of oxygen radicals and synthesis of lipid mediators such as $\mathrm{LTC}_{4}$, thromboxane $\mathrm{A}_{2}\left(\mathrm{TXA}_{2}\right)$, and prostaglandin $\mathrm{D}_{2}\left(\mathrm{PGD}_{2}\right)[63,64]$. Its effect on eosinophils can be substantially augmented after exposure of eosinophils to certain cytokines, such as interleukin-5 (IL-5) or GM-CSF [4, 65-70].

Both functional and binding studies suggest the presence of two binding sites for PAF on eosinophils with an apparent $\mathrm{kD}$ of $0.33 \mathrm{nM}$ and $11.5 \mathrm{nM}$, respectively [71]. Occupation of the high affinity PAF-RI receptor correlates with several functional responses, including degranulation and prostanoid release. In contrast, occupancy of the PAF-RII receptor is associated solely with the generation of $\mathrm{O}_{2}$ - radicals. The PAF receptor subsets utilize different signal transduction pathways with distinct intracellular second messengers and enzymes, which may account for their functional differences [71-73]. It is not clear, as yet, whether the two PAF receptors identified on eosinophils represent distinct binding sites, or whether they reflect two different affinity states of the same receptor.

Finally, several binding sites for cytokines have been detected on eosinophils, including the receptors for IL3, IL-5, and GM-CSF [74-78]. Interestingly, these receptors show mutual cross-inhibition on eosinophils but not on neutrophils $[74,75]$, which may be due to a limited expression of the common $\beta$-chain by eosinophils [79].

\section{Cellular constituents and products}

\section{Preformed granular constituents}

The eosinophil constitutes a number of enzymes and highly biologically active preformed basic proteins which are stored in their cytoplasmic granules (table 2). The electron-dense crystalloid core consists of major basic protein, and the surrounding matrix is composed of a number of basic proteins and various hydrolytic enzymes.

Four different cationic proteins are recognized in the specific eosinophil granules [80]: the major basic protein (MBP), ECP, eosinophil-derived neurotoxin or protein $\mathrm{X}$ (EDN or EPX), and eosinophil peroxidase (EPO). Each of these proteins have been cloned and their biochemical and functional properties are well-established [81-88]. The most abundant cationic eosinophil granule protein is MBP. It is an arginine residue rich $14 \mathrm{kDa}$ protein [82, 83, 85] devoid of any enzymatic activity, but highly toxic to helminthic parasites, tumour cells, and other mammalian cells and tissues. As will be 
Table 2. - Preformed enzymatic and nonenzymatic proteins of the human eosinophil leucocyte

\begin{tabular}{ll}
\hline Proteins & \multicolumn{1}{c}{ Biological actions } \\
\hline $\begin{array}{l}\text { Nonenzymatic proteins } \\
\begin{array}{l}\text { Major basic protein } \\
\text { (MBP) }\end{array}\end{array}$ & $\begin{array}{l}\text { Helminthotoxic, cytotoxic for tumour cells and other mammalian cells, activates mast cells, neutralizes } \\
\text { heparin }\end{array}$ \\
$\begin{array}{l}\text { Eosinophil cationic protein } \\
\text { (ECP) }\end{array}$ & $\begin{array}{l}\text { Affects coagulation factors, helminthotoxic, neurotoxic, activates mast cells, cytotoxic for various } \\
\text { mammalian cells, possesses RNase-activity }\end{array}$ \\
$\begin{array}{l}\text { Eosinophil-protein X } \\
\text { (EPX or EDN) }\end{array}$ & Strongly neurotoxic, helminthotoxic, inhibits lymphocyte cultures, RNAse-activity \\
Enzymatic proteins & \\
$\begin{array}{l}\text { Eosinophil peroxidase } \\
\text { (EPO) }\end{array}$ & Toxic for microorganisms, tumour cells and other mammalian cells, activates mast cells \\
$\begin{array}{l}\text { Collagenase } \\
\text { Arylsulphatase B }\end{array}$ & Hydrolyses Type I and Type II collagen (connective tissue of the lung) \\
\hline
\end{tabular}

EPX: eosinophil protein X; EDN: eosinophil-derived neurotoxic; RNase: ribonuclease.

outlined below, MBP has toxic properties independent of oxygen metabolism.

Like MBP, the "eosinophil cationic protein" (ECP) is a highly cationic protein, with toxic effects for helminthic and host cells. In addition, it shows a bactericidal activity [89]. ECP shares sequence similarities with the eosinophil-derived neurotoxin (EDN or EPX), and both polypetides are of approximately the same size, ranging between 18-21 kDa [81, 84, 90, 91]. Both ECP and EDN induce cerebellar dysfunction, when injected intracerebrally into rabbits [80, 91, 92], as first described by GORDON [93] in 1930 (Gordon-phenomenon). In addition, these proteins have both partial sequence identity with pancreatic ribonuclease and possess a ribonuclease catalytic activity. Whilst EDN is about 100 times more potent as a ribonuclease than ECP [81, 91], it is devoid of any cytotoxic activity against parasites and host cells.
The fourth basic protein is the eosinophil peroxidase, which consist of two polypetides of about 15 and $55 \mathrm{kDa}$ $[87,88,94,95]$. It is characterized by an overall negative charge but its major function comprises the formation of hypohalous acid in the presence of hydrogen peroxide and halide ions (preferentially bromide). Structurally and functionally EPO is distinct from the myeloperoxidase of neutrophils and monocytes and is toxic to helminthic and protozoan parasites, bacteria, tumour cells, and host cells [80, 96-99].

\section{De novo synthesized products}

Eosinophils have, for some time, been known to synthesize oxygen radicals and lipid mediators (table 3 ). However, the eosinophil, like the neutrophil, has been

Table 3. - De novo generated mediators by the human eosinophil leucocyte

\begin{tabular}{ll}
\hline Mediator & \multicolumn{1}{c}{ Biological actions } \\
\hline Lipids & Vasodilatation, mucus secretion, inhibition of inflammatory cells \\
$\mathrm{PGE}_{2}$ & Bronchoconstriction, pulmonary vasoconstriction, increase in vascular permeability, platelet aggregation \\
$\mathrm{PGD}_{2}$ & Bronchoconstriction, platelet aggregation \\
$\mathrm{PGF}_{2 \alpha}$ & Bronchial and vascular constriction, platelet aggregation \\
$\mathrm{TxA}_{2}$ & Bronchial and vascular constriction, increase in vascular permeability \\
$\mathrm{LTC}_{4}$ & Bronchial and vascular constriction, bronchial oedema, platelet aggregation, mucus secretion, activation \\
$\mathrm{PAF}$ & of neutrophils, mast cells and eosinophils \\
$\mathrm{ECL}$ & Eosinophil chemoattractant
\end{tabular}

\section{Oxygen metabolites}

Superoxide anion Hydrogen peroxide Singlet oxygen

Cytokines

IL-3

GM-CSF

TGF- $\beta 1$

\section{Neuropeptides}

VIP

Substance P
Toxic for micro-organisms, tumour cells and other mammalian cells

Toxic for micro-organisms, tumour cells and other mammalian cells

Toxic for micro-organisms, tumour cells and other mammalian cells

Priming and activation of inflammatory cells, granulocyte differentiation, enhances survival Priming and activation of inflammatory cells, granulocyte differentiation, enhances survival Activation of fibrocytes, Th2 cytokines inhibition

Bronchoconstriction, vasodilatation

Bronchoconstriction, vascular oedema, vasodilatation, stimulates mucus secretion, degranulation of mast cells

$\mathrm{PGE}_{2}$ : prostaglandin $\mathrm{E}_{2} ; \mathrm{PGD}_{2}$ : prostaglandin $\mathrm{D}_{2} ; \mathrm{PGF}_{2 \alpha}$ : prostaglandin $\mathrm{F}_{2 \alpha}$ : TxA $\mathrm{A}_{2}$ : thromboxane $\mathrm{A}_{2} ; \mathrm{LTC}_{4}$ : leukotriene $\mathrm{C}_{4}$ : PAF: platelet-activating factor; IL-3: interleukin-3; GM-CSF: granulocyte/macrophage colony-stimulating factor; TGF- $\beta 1$ : tumour growth factor- $\beta 1$ : VIP: vasoactive intestinal peptide; ECL: eosinophil chemotactic lipid. 
assumed to be a short-lived, end-stage effector cell, with little or no capacity for protein synthesis. However, this assumption about the capabilities of mature eosinophils is probably not warranted. Blood eosinophils cultured in the presence of GM-CSF and murine 3T3 fibroblast [38], or eosinophils obtained from bronchoalveolar space during chronic inflammation [35, 37, 42], synthesize and express human leucocyte antigen-DR (HLA-DR), exemplifying the principal capacity of mature eosinophils to synthesize proteins. In addition, recent studies employing in situ hybridization suggest that eosinophils express the gene for GM-CSF, IL-3 and transforming growth factor- $\beta 1$ (TGF- $\beta 1$ ) [100-103]. Further, ionomycinactivated human eosinophils also gave specific immunocytochemical staining with $\alpha$-human-cytokines [101], providing evidence for translation of cytokine messenger ribonucleic acid (mRNA). These data suggest that the mature eosinophil is not only capable of releasing de novo generated lipid mediators and oxygen radicals but can also synthesize new proteins.

Oxygen radicals. Eosinophils respond to stimulation with a respiratory burst generating toxic oxygen radicals, such as $\mathrm{O}_{2}^{-}$[104-106], $\mathrm{H}_{2} \mathrm{O}_{2}[104,105,108-110]$, and probably $1 \mathrm{O}_{2}$ as well as $\mathrm{OH} \cdot[111,112]$. With most stimuli, the respiratory burst of eosinophils is greater than that of equivalent numbers of neutrophils [104, 105, 107, 109, 113]. A reduced nicotinamide adenine dinucleotide (NADPH) oxidase, similar to that present in neutrophils, appears to be involved [104, 106, 107]. NADPH oxidase activity was reported to be three to six times greater in eosinophils than in comparable neutrophil preparations [104], and eosinophils contain a cytochrome $b_{559}$ concentration that is twice that of neutrophils or monocytes [114].

Lipid mediators. Stimulation of human and animal eosinophils with various soluble and nonsoluble agents leads to the formation of various arachidonic acid-derived lipids, including $\mathrm{LTC}_{4}$ [63, 69, 115-117], PGE [118, 119], prostaglandin $\mathrm{F}_{1}\left(\mathrm{PGF}_{1}\right)$ and $\mathrm{TxA}_{2}$ [64, 119-123], $\mathrm{PGD}_{2}$ and prostaglandin $\mathrm{F}_{2 \alpha}\left(\mathrm{PGF}_{2 \alpha}\right)[64,123]$. In addition, eosinophils have been shown to synthesize large amounts of PAF [117, 124-126].

Cytokines. Recent work has demonstrated that eosinophils contain the genetic information for a number of cytokines. Various studies employing in situ hybridization suggest that eosinophils express the genes for GM-CSF, IL-3 and TGF- $\beta 1$ as well as transforming growth factor- $\alpha$ (TGF$\alpha)$ [100-103]. In addition, the cytokines could be detected immunocytochemically in human eosinophils when stained with monoclonal antibodies, providing evidence for translation of cytokine mRNA [100, 102]. Finally, IL3 and GM-CSF were measured in ionomycin-stimulated supernatants [101]. The ability to release cytokines represents a new method by which eosinophils may contribute to inflammatory and immunological responses.

Neuropeptides. Neuropeptides represent a group of neurotransmitters which have originally been identified in neuronal tissue. However, recent studies have shown that some of these peptides, such as substance P (SP), vasoactive intestinal peptide (VIP) or somatostatin (SOM), are also released by immune cells and serve to modulate cytokine secretion by regulatory T-lymphocytes [127]. Eosinophils within the liver and intestinal granulomas of the mouse synthesize VIP and SP [128-130). In addition, eosinophils have been demonstrated to release SP in vitro when exposed to histamine via activation of a H1 type receptor [129]. Furthermore, SP but not VIP has been shown to induce eosinophil degranulation, albeit through a toxic mechanism [131]. Hence, it appears that eosinophils also regulate local inflammation through the release of neuropeptides.

\section{Eosinophil heterogeneity}

When examined under in vitro or in vivo conditions, eosinophils show differences in their morphological, phenotypical, physical and functional status (table 4). The significance of cellular heterogeneity is not yet known, but it may reflect a certain phase in the life cycle of the cell and facilitate adaptation of the eosinophil to the

Table 4. - Characteristic cellular changes of the eosinophil following activation in vitro and in vivo

\begin{tabular}{|c|c|}
\hline Cellular changes & Consequences \\
\hline \multicolumn{2}{|l|}{ Morphology } \\
\hline $\begin{array}{l}\text { Dissolution of secondary } \\
\text { granules }\end{array}$ & Degranulation \\
\hline Increase in cell volume & Hypodensity \\
\hline Large empty vacuoles & Hypodensity \\
\hline Vesiculotubular structures & Degranulation, metabolism \\
\hline \multicolumn{2}{|l|}{ Phenotype } \\
\hline $\begin{array}{l}\text { Increased expression of } \\
\text { surface antigens }\end{array}$ & $\begin{array}{l}\text { CD11a } \\
\text { CD11b }\end{array}$ \\
\hline \multirow{6}{*}{ Induction of surface antigens } & CD13 \\
\hline & LFA-3 (CD58) \\
\hline & HLA-DR \\
\hline & CD69 \\
\hline & CD4 \\
\hline & ICAM-1 (CD54) \\
\hline \multirow{5}{*}{$\begin{array}{l}\text { Decreased expression of } \\
\text { surface antigens }\end{array}$} & CD35 \\
\hline & CDw32 \\
\hline & VLA- $\beta$-chain (CD29) \\
\hline & VLA- $\alpha$-chain (CD49d) \\
\hline & PECAM-1 (CD31) \\
\hline Loss of surface antigens & L-selection \\
\hline \multicolumn{2}{|l|}{ Density } \\
\hline $\begin{array}{l}\text { Decrease in cellular density } \\
\text { (hypodense cells) }\end{array}$ & $\begin{array}{l}\text { Proportion }>10 \% \text { of all cells } \\
\text { (specific weight }<1.082 \mathrm{~g} \cdot \mathrm{ml}^{-1} \text { ) }\end{array}$ \\
\hline \multicolumn{2}{|l|}{ Function } \\
\hline Desensitization & $\begin{array}{l}\text { Transient, i.e. following } \\
\text { exposure to PAF or other stimuli }\end{array}$ \\
\hline Hypersensitization (priming) & $\begin{array}{l}\text { Induced by cytokines and low } \\
\text { concentrations of other } \\
\text { mediators }\end{array}$ \\
\hline
\end{tabular}

LFA-3: leucocyte function associated antigen-3; HLA-DR: human leucocyte antigen-DR; ICAM-1: intercellular adhesion molecule-1; VLA: very late activation antigen; PECAM-1: platelet endothelial cell adhesion molecule. 
changing conditions or microenvironment during an acute inflammatory process. Cellular heterogeneity, however, is not specific for eosinophils, and has been also observed in alveolar macrophages [132] and neutrophils [133, 134].

\section{Morphological heterogeneity}

Eosinophils from patients with eosinophilia are morphologically distinct when compared to cells obtained from healthy subjects. The cells are characteristically hypodense and other changes include the appearance of cytoplasmic vacuoles, alteration in cell size and shape, increase in granule size, solubilization and loss of granular core and matrix proteins, together with an increase in vesiculotubular structures and smooth tubules and vesicles [8, 135]. Similar changes can be induced by exposure of eosinophils to cytokines or PAF in vitro $[3,4,65,66,135,136]$ suggesting that the morphological heterogeneity of eosinophils is caused by inflammatory mediators in vivo.

\section{Phenotypical heterogeneity}

It is an inherent property of cells to modify the expression of surface receptors, and eosinophils are no exception. Some receptors may be upregulated, as has been shown for the complement receptors, and adhesion molecules $[19,43,137,138]$. Others are only synthesized and expressed in primed or activated eosinophils, such as Class II proteins of the major histocompatibility complex, CD4, ICAM-1 or IL-2 [37-42, 53, 139]. Others again, such as L-selectin are shed during eosinophil activation and transendothelial migration [35, 43].

An experimental approach in order to characterize such principal phenotypic changes of eosinophils undergoing activation is to compare bronchoalveolar lavage (BAL) and blood cells from different diseases [140]. As has recently been demonstrated, BAL eosinophils obtained from patients with atopic asthma and eosinophilic pneumonia showed an upregulation of the $\beta_{2}$-integrins CD11b and CD11c, the aminopeptidase N (CD13), the glycoprotein $\mathrm{CD} 24$, the tyrosine phosphatase CD45, as well as the leucocyte function antigen-3 (CD58) by 51-222\%. In contrast, the $\beta$-integrins CD29 and CDw49 (VLA-4), the $\beta_{2}$-integrin CD11a, the Fc $\gamma$ RII (CDw32), the complement receptor CR1 (CD35) and other antigens (CD15, CD63, HLA-ABC) were downregulated by $30-73 \%$. Furthermore, in both diseases the "intercellular adhesion molecule-1" (ICAM-1) was induced on BAL eosinophils, whilst Lselectin was shed by 94 and 98\%, respectively. Interestingly, significant levels of the HLA-DR antigen were exclusively detected on BAL eosinophils from eosinophilic pneumonia; whereas, eosinophils obtained during the asthmatic late response from both BAL and peripheral blood did not express this class II major histocompatibility complex (MHC) antigen. Since expression of HLA-DR requires de novo synthesis, the reason why eosinophils $18 \mathrm{~h}$ postantigen challenge do not express this antigen may simply be the limited time. The above data, however, suggest that tissue infiltrating eosinophils obtained during active disease undergo similar phenotypical changes, indicating a general mechanism of activation during recruitment into lung airways (see below).

The phenotypic changes observed in vivo can be imitated by appropriate treatment of native blood cells in vitro. For instance, blood eosinophils stimulated in vitro with IL-5, PAF or fMLP achieved similar levels of CD11b and VLA-4 expression as BAL eosinophils obtained 18 $\mathrm{h}$ post-challenge [20,138, 141-144]. The stimuli also caused a decrease in L-selectin expression in eosinophils. Interestingly, whilst PAF and fMLP also induced comparable changes in neutrophils, IL-5 selectively affected the surface expression of adhesion molecules in eosinophils [141]. In contrast to blood cells, surface antigen expression on BAL eosinophils obtained $18 \mathrm{~h}$ post-challenge could not be further modified by either stimulus ex vivo [138]. Blood eosinophils cultured in vitro for 2 days in the presence of IFN- $\gamma$ showed an upregulation of Fc $\gamma$ RII (CDw32), and induced the expression of Fc $\gamma$ RI (CD64) as well as a functionally active FcyRIII (CD16) receptor [23]. Taken together, these data suggest that surface receptor expression in eosinophils in vitro or in vivo follows a similar pattern, and indicates that eosinophils undergo activation during the recruitment process into the tissue.

\section{Density heterogeneity}

Eosinophils from healthy donors have the highest density of human peripheral blood leucocytes, and it is this property which forms the basis of the purification technique using density gradients. However, blood from patients with eosinophilia-associated diseases, such as the hypereosinophilic syndrome (HES), parasitic infection or allergy, contains a population of eosinophils which separate at a lower buoyant density. This population is termed "hypodense", as opposed to "normodense" eosinophils from normal individuals mentioned above [145]. Whilst normodense eosinophils represent approximately $90 \%$ of the cells found in normal subjects [146-148], peripheral blood eosinophils from patients with certain eosinophilassociated diseases, such as allergic rhinitis [149], asthma [146, 147, 150, 151], allergic bronchopulmonary aspergillosis and helminthic parasite infestation [2, 148], or an eosinophilic-myalgia-like syndrome [152], show an increased proportion of hypodense cells. In asthma, the mean percentage of hypodense blood eosinophils for patients with asthma in three studies varied between 35 and $65 \%[146,147,150]$. In other active hypereosinophilic diseases, hypodense cells may account for up to $80 \%$ of the eosinophils [152].

In addition to blood cells, BAL eosinophils also constitute a high proportion of hypodense cells. This has been shown for eosinophils in the BAL fluid obtained from allergic asthmatics $48 \mathrm{~h}$ post-segmental allergen challenge [138, 153], chronic eosinophilic pneumonia [148, 154], as well as for other eosinophil-related disorders. In addition, a raised number of hypodense eosinophils have been found in pleural fluid recovered from patients with various lung diseases [148, 155].

The nature of this density heterogeneity and the mechani$\mathrm{sm}(\mathrm{s})$ underlying the development of hypodense eosinophils 
is not yet known. In principle, hypodense eosinophils may represent: 1) a more mature, activated cell; 2) an immature cell; 3) a separate lineage of eosinophils; or 4) some combination of the above possibilities. However, the data so far available support the first hypothesis. Firstly, when exposed to PAF in vitro, eosinophils undergo a time and concentration-dependent shift towards lower densities relative to the unstimulated control cells, thereby increasing the proportion of hypodense cells from $9 \%$ to $28 \%$ after $60 \mathrm{~min}$ and to $82 \%$ after $120 \mathrm{~min}$ [136]. The light-density eosinophils were found to be degranulated, contained less granules, showed an increase in cell volume, and upregulation of adhesion molecules [23, 136]. Similar morphological and phenotypic features were observed in the hypodense blood eosinophils of patients with allergy, eosinophilic pneumonia or parasitic infection $[2,18,37,145]$. Secondly, incubation of normodense eosinophils, either with IL-3, IL-5 or GM-CSF, in the presence or absence of 3T3 fibroblasts, not only prolongs survival of eosinophils but also induces them to become hypodense (see reviews [65, 145]).

Taken together, these data clearly indicate that exposure of eosinophils to one or more mediators of inflammation induces a shift towards lower cell densities. Hence, a raised proportion of hypodense eosinophils may reflect activation of the cell and, in turn, an actively ongoing disease state. Since the cell density is determined by the ratio of cell weight to cell volume, the data so far available suggest that both loss of granular proteins and an increase in cell volume may contribute to the reduction of density in eosinophils [136].

\section{Functional heterogeneity}

The functional relevance of hypodense eosinophils is not yet understood and the data available appear somewhat conflicting. For instance, low density eosinophils from HES patients are cytotoxic to IgE-coated schistosomula, whilst normodense eosinophils are cytotoxic to IgGcoated schistosomula [156]. Secretion of eosinophil peroxidase by low density eosinophils from HES patients is caused by stimulation with antigen or anti-IgE, whilst normodense eosinophils from HES patients respond to anti-IgG [157]. In addition, eosinophils from patients with parasitic diseases show a slightly reduced density and an increased cytotoxicity towards IgG-coated chicken erythrocytes [158]. Low density eosinophils obtained in vitro by incubation with GM-CSF are cytotoxic to IgGcoated schistosomula [65]. Furthermore, light density eosinophils from patients with HES generate and release greater amounts of leukotriene $\mathrm{C}_{4}$ in response to IgG- or complement-coated targets and the monocyte-derived eosinophil-activating factor (EAF) than do normal density eosinophils $[155,159,160]$. Low density eosinophils from patients with HES show an increased deoxyglucose uptake and oxygen consumption and incorporation of PAF into the phospholipid pool than normodense cells $[155,161,162]$ indicating a higher metabolic activity in light density eosinophils.

However, in contrast, some other studies indicate that hypodense eosinophils may also occur in a hyporeactive state. For instance, hypodense cells obtained from asth- matic subjects produced a lower amount of reactive oxygen metabolites in response to zymosan and phorbol myristate acetate (PMA), as assessed by nitro blue tetrazolium (NBT) reduction and chemiluminescence [4, 147]. In addition, low-density eosinophils obtained from asthmatic subjects produced only half the amount of $\mathrm{LTC}_{4}$ compared with normodense cells [115]. Furthermore, BAL, eosinophils from asthmatic subjects obtained $18 \mathrm{~h}$ post-allergen challenge showed a reduced capacity to generate prostanoids compared to blood eosinophils [163].

The reason for this discrepancy is not yet clear. Since an array of mediators are released during asthmatic inflammation [153, 164, 166], which may be responsible for both chemotactic attraction to the inflammatory focus and stimulation of cellular effector functions, the attenuated functional capacity of BAL eosinophils may be due to a cellular desensitization process, as has been previously described for eosinophils [72, 73, 167]. Interestingly, neutrophils recruited to the lung following segmental antigen provocation have also been found to be desensitized to $\mathrm{LTB}_{4}$ [168], suggesting that desensitization during tissue infiltration may be a necessary general process for accumulation at the spot with the highest level of chemoattractant. If this is true, one may hypothesize that hypodensity of eosinophils does not simply reflect cellular hyperreactivity. In contrast, the functional reagnicity of eosinophils in relation to their density may be rather variable, depending on what factors the cell is exposed to in the microenvironment of the bronchial tissue, and could be controlled by inherent cellular feedback mechanisms which serve to protect the cell against overstimulation.

\section{Activation and priming}

An increasing number of substances with potential eosinophil-activating properties have been identified (table 5). Among them, calcimycin, also known as the $\mathrm{Ca}^{2+}$ ionophore A23187, a polyether antibiotic produced by Streptomyces chartreusensis, and the tumour-promoting agent, PMA, represent valuable tools for evaluating the potential role of either $\mathrm{Ca}^{2+}$ or protein kinase $\mathrm{C}$ (PKC) and their interaction in eosinophil activation. However, since these agents are nonphysiological and cytotoxic at certain concentrations $[146,169,170]$ they have no pathophysiological significance in vivo. Other factors, such as the mast cell-derived acidic tetrapeptides, Val-GlySer-Glu and Ala-Gly-Ser-Glu (eosinophil chemotactic factor of anaphylaxis (ECF-A)), which have been studied at several laboratories in recent years and which were considered to be selective eosinophil chemoattractants [171], are now known not only to be ineffective in vivo [172] but also to show negligible activity in vitro when compared to other stimuli [173, 174].

An increasing number of physiological agents that stimulate eosinophils have been identified, including lipid mediators such as $\mathrm{LTB}_{4}$ or PAF, cytokines, immunoglobulins and tachykinins such as substance $\mathrm{P}[65,131$, $175,176]$, all of which may be best divided on the basis of their chemical structure and molecular weight into lipids, peptides and proteins. 
Table 5. - Major currently-known eosinophil-activating factors subdivided according to their chemical nature

\begin{tabular}{ll}
\hline Chemical class & \multicolumn{1}{c}{ Mediator } \\
\hline Lipids & Platelet-activating factor (PAF) \\
& Leukotriene B \\
& 8S, 15S-DiHETE \\
& $5,15-$ DiHETE \\
& Eosinophil chemotactic lipid (ECL) \\
& Arachidonic acid \\
& \\
Proteins & Granulocyte/macrophage-colony- \\
Cytokines & stimulating factor (GM-CSF) \\
& Interleukin-2 \\
& Interleukin-3 \\
& Interleukin-5 \\
& MIP-1 $\alpha$ \\
& RANTES \\
Complement factors & C5a \\
Immunoglobulins & Immunoglobulin G $_{2}$ \\
Other & Immunoglobulin A (dimer) \\
& Phorbol myristate acetate (PMA) \\
& Ca ${ }^{2+}$-ionophore A23187 (calcimycin) \\
\hline
\end{tabular}

DiHETE: dihydroxyeicosatetraenoic acid; MIP1 $\alpha$ : macrophage inflammatory protein- $1 \alpha$. TPA: tissue polypeptide antigen; RANTES: regulated upon activation in normal T-cells expressed and secreted.

Lipids. Lipid mediators are derivatives of the membrane phospholipids and are de novo generated upon stimulation of the cell. Among them, leukotrienes and PAF have been implicated in the pathogenesis of various inflammatory diseases [175]. In asthma, for instance, PAF appears to represent one of the most effective mediators, capable of inducing bronchoconstriction [177, 178], microvascular leakage [179, 180], and airway hyperresponsiveness in animals [181] and humans [182]. Hence, PAF can mimic many of the changes occurring during the late asthmatic response. Furthermore, it has been demonstrated that PAF is a potent stimulus for several inflammatory cells, including eosinophils, and might be an important factor responsible for inflammatory cell infiltration in asthma [183-185]. In addition, there is evidence that eosinophil responsiveness to PAF may even increase during active disease [173, 186, 187]. PAF-elicited a spectrum of eosinophil functions, such as eosinophil chemotaxis, in vitro [173] and in vivo [188-191], eosinophil adhesion to endothelial cells [46, 192-194], eosinophil cytotoxicity against parasites [195], generation of superoxide anions [187, 196], release of granular enzymes and proteins [187, 196-198], and a shift in density from normodense to hypodense eosinophils [136] and several cyclooxygenase-derived arachidonic acid metabolites [64, 119, 121].

Not only is PAF a potent eosinophil-activating factor, but eosinophils are also the major source of this mediator [125]. As with other cells, this observation suggests that cells capable of producing a certain lipid mediator also respond to it. A major role of the lipids, therefore, may be to attract more effector cells to an inflammatory site through an amplification loop. In addition, PAF may function as an autocoid, modulating the eosinophil response induced by other agonists, such as C5a or fMLP. Such a function has been attributed to the mode of action of interleukin-2 in T-helper cells. Evidence to support this hypothesis in eosinophils can be drawn from results showing that the PAF receptor antagonist WEB 2086 partially inhibits thromboxane $\mathrm{B}_{2}\left(\mathrm{TxB}_{2}\right)$ release from eosinophils stimulated with calcimycin [73, 119]. Hence, the release of PAF by eosinophils upon stimulation may result in an autocrine response amplification loop. However, PAF synthesized in eosinophils tends to remain cellassociated [125], and the possible role of PAF as an autocoid in eosinophil activation awaits further investigation.

A couple of studies indicate that PAF, in addition to its direct stimulatory effect, may also prime eosinophils $[116,199]$. For instance, preincubation of human blood eosinophils with PAF for $30 \mathrm{~min}$, significantly enhanced the calcimycin-induced $\mathrm{LTC}_{4}$ production [116], as well as the respiratory burst induced by serum-treated zymosan [199], whereas $\mathrm{LTB}_{4}$ failed to enhance the eosinophil mediator production [116]. Hence, taken together PAF would perfectly link the pathophysiological changes observed in asthma with the infiltration and activation of eosinophils. Unfortunately, however, PAF is not selective and acts on both neutrophils and eosinophils [186], suggesting that other mediators may also be operative in eosinophil recruitment (see below).

Peptides. A number of peptides have been shown to stimulate eosinophils. SP induces eosinophil granular protein release, though presumably via a nonspecific mechanism [131]. Formyl-methionine-containing peptides such as fMLP are chemotactic for a number of cell types and show certain similarities to chemotactic factors produced by bacteria. Eosinophils express specific fMLP receptors $[131,200]$, and respond to the tripeptide with chemotaxis, degranulation, superoxide anion generation, and prostanoid production [73, 131, 200-202]. Although its effect is small compared to other stimuli, overnight culture of the cells in monocyte-conditioned medium substantially increases both receptor expression and eosinophil functional responses [200].

Proteins. Various classes of proteins, including immunoglobulins, complement factors and cytokines, possess chemotactic and stimulatory activities for eosinophils. Using rosetting techniques, IgG receptors had been demonstrated on eosinophils as early as 1969 [203]. More recent work has confirmed that mature eosinophils bear the Fc $\gamma$ RII receptor [19, 23, 204], which is known to bind to multivalent ligands [205]. Thus, the eosinophil tends to bind to large surfaces coated with antibody, such as parasites. IgG receptor activation causes the generation of $\mathrm{LTC}_{4}$, respiratory burst and secretion of granular contents [170, 206]. In addition to Fc $\gamma$ RII sites, receptors for $\mathrm{IgE}$ have been described on eosinophils [26, 27], and activation of this receptor promotes the release of granular proteins and PAF [24, 25]. However, the IgE receptor on eosinophils has not been fully characterized and appears not to be completely identical to FceRII (CD23), the low-affinity $\mathrm{IgE}$ receptor on lymphocytes, monocytes and other cells [28]. Finally, monomeric $\operatorname{IgA}$, and in particular secretory $\operatorname{Ig} \mathrm{A}(\operatorname{sig} \mathrm{A})$, have recently been shown to be potent eosinophil degranulating agents [32]. 
In addition, complement proteins, such as C3a and C5a, (assessed using opsonized parasites, zymosan or sepharose) have been implicated as eosinophil activators that facilitate chemotaxis (i.e. C5a) and binding of eosinophils to large surfaces, thereby inducing secretion of granular contents [2, 207-210]. In addition, C5a elaborates protein release, oxygen burst, and lipid prostanoid generation in human eosinophils [119, 196, 211, 212].

In recent years, an increasing number of cytokines relevant to eosinophils have been identified (table 6). For instance, the haematopoietic cytokines, IL-3, IL-5 and GM-CSF promote eosinophilopoiesis in vivo, prolong eosinophil survival and modulate eosinophil function in vitro (for review see [213]). Human peripheral-bloodderived normodense eosinophils cultured for 7 days with IL-3 [65] or GM-CSF [3, 66, 67, 214] generate increased amounts of $\mathrm{LTC}_{4}$ and enhanced cytotoxicity toward schistosomula when challenged with calcimycin. Evaluation of the cell density revealed that exposure of eosinophils to the cytokines converted them to a hypodense phenotype. A similar effect on eosinophil releasability was observed with IL-5 [75, 215]. FuJISAWA et al. [216] demonstrated that preincubation of normal eosinophils with IL-3, IL-5 or GM-CSF also enhanced the sIgA- and IgG-induced release of EDN. IL-5 was the most potent enhancer of immunoglobulin-mediated degranulation and its effect was apparent within $15 \mathrm{~min}$. IL-5 also enhances eosinophil adhesion to endothelial cells [217] and induces eosinophil chemotaxis in vitro [218] and in vivo [219]. The particular significance of IL-5 for eosinophil-related inflammation is its selective action on eosinophils but not on neutrophils [220, 221].

In addition to their priming effect, cytokines elicit a direct stimulatory action on eosinophils. For instance, GM-CSF and IL-5 induced a small but significant release of EDN. Whilst IL-2 has no effect on degranulation, IL-2 together with the lymphocyte chemoattractant factor (LCF) has been shown to be by far the most potent eosinophil chemoattractant $[40,55]$. Systemic or intrapleural administration of IL-2 induced a significant eosinophilia in the peripheral blood [222-224] and pleural fluid [225], respectively. The migratory response of eosinophils is mediated by the high affinity IL-2 receptor as evidenced by the molar potency of IL-2 as an eosinophil chemoattractant and by the ability of monoclonal antibodies to inhibit IL-2-induced chemotaxis [40].

LCF is a $56 \mathrm{kDa}$ basic glycoprotein, that is elaborated by CD8+ human T-lymphocytes [226, 227]. LCF utilizes CD4 as its receptor and stimulates the migration of CD4+ mononuclear cells [226]. As has been mentioned above, CD4 expression is also detectable on eosinophils obtained from both normal donors and those with eosinophilia $[53,55]$, albeit at appreciably lower levels than found on T-helper cells. Since LCF does not stimulate migration of neutrophils, which lack CD4 expression, the mediator may contribute to the preferential tissue influx of both eosinophils and CD4+ lymphocytes in related disease.

Within the past 2 yrs more cytokines with chemotactic properties, which are members of a structurally-related low molecular weight platelet factor $4 /$ intercrine/chemokine

Table 6. - Cellular sources and biological actions of eosinophil regulatory cytokines

\begin{tabular}{lll}
\hline Cytokine & Cell sources & \multicolumn{1}{c}{ Biological action } \\
\hline GM-CSF & T-lymphocytes & Augments cell viability, adherence, degranulation, phagocytosis, superoxide \\
& Mast cells & anion production, leukotriene $\mathrm{C}_{4}$ generation, and cytoxicity \\
& Eacrophages & Reduces cell density \\
& Eosinophils & Stimulates proteoglycan synthesis \\
IL-1 & Many cell types & Upregulates CD11b, LFA-1 and PAF receptor expression \\
IL-2 & T-lymphocytes & Augments adherence to endothelial cells and degranulation \\
IL-3 & T-lymphocytes & Eosinophil chemoattractant \\
& Mast cells & Augments viability, leukotriene generation and cytotoxicity \\
& Eosinophils & Reduces cell density \\
IL-5 & T-lymphocytes & Stimulates proteoglycan synthesis \\
& Mast cells & Augments viability, leukotriene generation and cytotoxicity \\
& Eosinophils & Reduces cell density \\
& Stimulates proteoglycans synthesis \\
LCF & CD8+ T-lymphocytes & Epregulates surface antigen expression \\
TNF- $\beta$ & Various cell types & Augments adherence to endothelial cells and weak cellular cytotoxicity \\
IFN- $\gamma$ & T-lymphocytes & Augments viability \\
& Various cell types & Increases cytotoxicity (delayed acting) \\
IFN- $\alpha$ & Lymphocytes & Augments viability (weak) \\
MIP-1 $\alpha$ & Eosinophils & Eosinophil attractant \\
RANTES & Plymphocytes & Potent eosinophil chemoattractant \\
& Induces ECP and oxygen radical release \\
\hline
\end{tabular}

TNF: tumour-necrosis factor; IFN: interferon; ECP: eosinophil cationic protein; LCF: lymphocyte chemoattractant factor. For further abbreviations see legend to tables 3 and 5. 
superfamily, have been identified. Although previously recognized as a neutrophil attractant, interleukin-8 (IL8 ), a member of the C-X-C branch of the superfamily, has been shown to attract and activate eosinophils previously primed with IL-3, IL-5 or GM-CSF [228]. In addition, both macrophage inflammatory protein- $1 \alpha(\mathrm{MIP}-1 \alpha)$ and RANTES, two members of the C-C branch, are potent eosinophil attractants $[229,230]$ with a similar efficacy to the most potent chemotactic myeloid cell agonists, C5a and PAF. RANTES also induced secretion of ECP and oxygen radical release by human eosinophils [230]. Since RANTES also attracts CD45RO+ (memory) Tcells [231] but no neutrophils, local production of RANTES by activated T-cells and platelets may account, in part, for the characteristic inflammatory infiltrate observed in allergic disease.

\section{Interaction with other cells}

The eosinophil is an immunological cell and, as such, part of a highly complex system which requires a constant flow of mutual information among other participating cells. Multiple mechanism by which eosinophils may interact with other immunological cells have been suggested over the past years and will be outlined below (fig. 4).

\section{Mast cells and basophils}

Although of different origin, mast cells and basophils share a number of properties, including not only FceRI expression and mediator content but also with respect to possible co-operation with eosinophils. For instance, a number of studies have demonstrated that MBP, ECP and EPO induce a non-cytolytic release of histamine both from human basophils [223, 232-238] and mast cells [239-241]. However, whilst basophils circulate in the blood and infiltrate tissue during late phase allergic reactions, mast cells are normally distributed throughout connective tissue [232, 233] and represent the first line inflammatory cell when exposed to allergen in atopic disease.

It has been shown that EPO binds to the negativelycharged mast cell granule to form a complex that retains toxic activity to bacteria [242] and tumour cells [243] when supplemented with $\mathrm{H}_{2} \mathrm{O}_{2}$ and a halide [242, 244]. Since EPO at high $\mathrm{H}_{2} \mathrm{O}_{2}$ concentrations and the EPO/ $\mathrm{H}_{2} \mathrm{O}_{2} /$ halide complex at lower $\mathrm{H}_{2} \mathrm{O}_{2}$ concentrations can initiate mast cell granule release [245], it is conceivable that mast cells and eosinophils may act synergistically to improve host defence. On the other hand, mast cell granules released during inflammation may contribute to the tissue irritation caused by other eosinophil proteins. It has been suggested that mast cells, which normally contain a small amount of granular peroxidase activity [244], may internalize exogenous EPO using a vesicular transport system and incorporate the peroxidase in their cytoplasmic granules [243, 246, 247].

Conversely, human mast cells and basophils may also counteract the toxic principles derived from eosinophils. For instance, a number of studies have demonstrated that human mast cells and basophils rapidly sequester toxic eosinophil proteins by endocytosis [248-250]. This observation may provide an explanation for the presence of MBP or EPO in basophils and mast cells [248, 251].

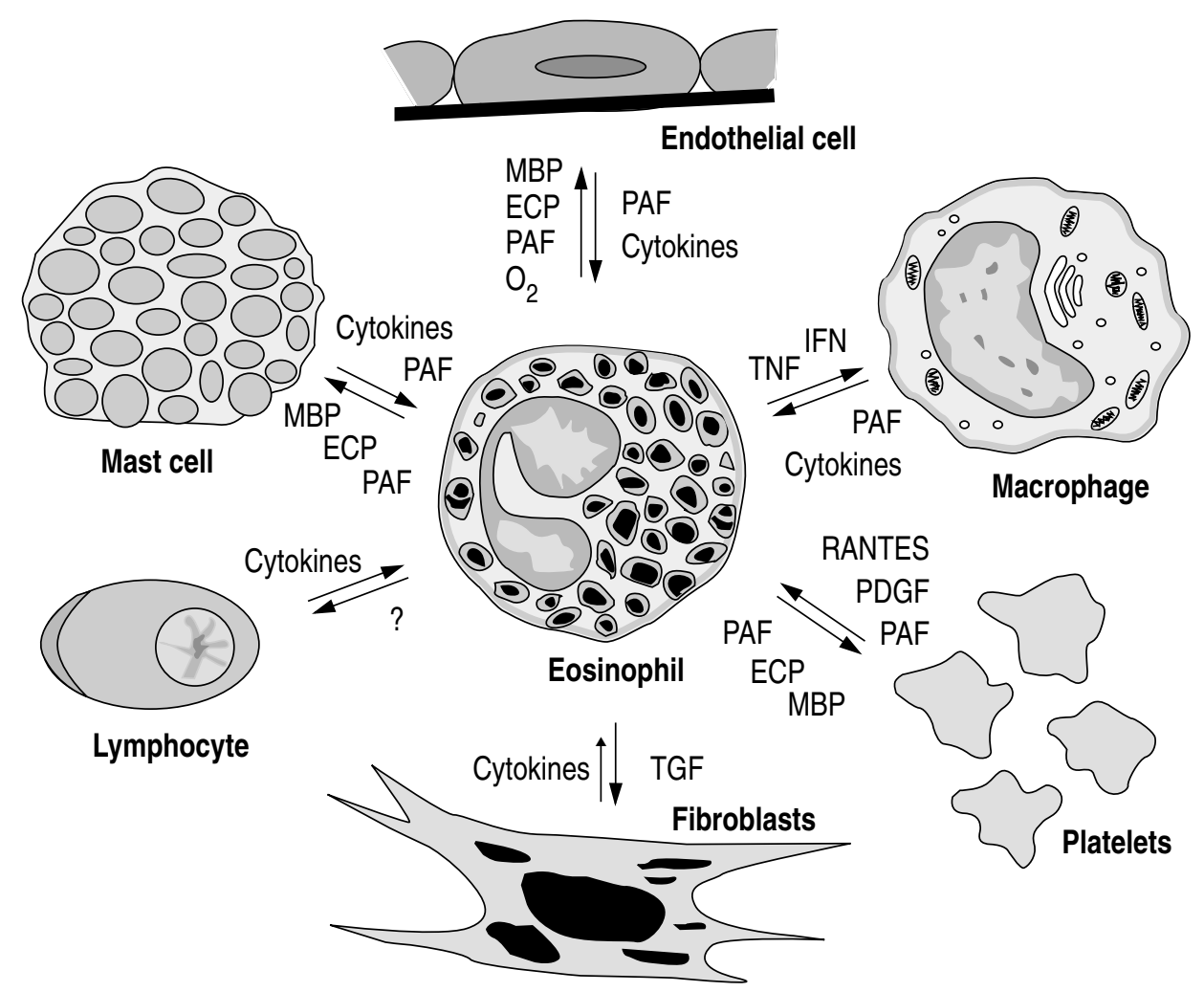

Fig. 4. - Possible interaction of eosinophils with other immune cells. MBP: major basic protein; ECP: eosinophil cationic protein; PAF: plateletactivating factor; IFN: interferon; TNF: tumour necrosis factor; PDGF: platelet-derived growth factor; TGF: transforming growth factor. 
In addition, heparin and related anionic molecules, which bind histamine within mast cell and basophil granules, neutralize the toxic properties of MBP, as has been demonstrated for bronchial epithelial cells [252, 253] and tumour cells [254].

Finally, mast cell- and basophil-derived mediators, such as PAF or cytokines, may facilitate the function of eosinophils [233]. Since mast cells have been implicated in the immediate reaction in IgE-dependent hyperreactivity, the release of these mediators may contribute to the pathogenesis of the delayed infiltration of other inflammatory cells, such as eosinophils, in late allergic reaction.

\section{Neutrophils and macrophages}

Both neutrophils and macrophages may contribute to eosinophil-dominated inflammatory reaction via release of eicosanoids and reactive oxygen species and cytokines [255-258]. Toxic properties by intact neutrophils and macrophages are considerably increased when eosinophil-derived EPO is bound to the target cell surface, presumably due to a more sufficient utilization of $\mathrm{H}_{2} \mathrm{O}_{2}$ by the phagocytes [259]. This has been shown by the efficacy of macrophages in killing staphylococci [260], toxoplasma [261], and trypanosoma [262] as well as for macrophage-mediated cytolysis of neoplastic cells in vitro [263].

In addition, eosinophils may activate neutrophils through the release of granular proteins. A recent study suggests that MBP is capable of inducing oxygen radical and lysozyme release by neutrophils in a noncytotoxic concentration-dependent fashion, whereas other eosinophilderived granular proteins had no effect [264]. A similar effect of eosinophil granular proteins has been proposed for macrophages [265].

Since both neutrophils and macrophages produce a number of mediators themselves, it is likely that they in turn are also capable of modulating eosinophil function. For instance, in vitro studies have demonstrated that supernatants of alveolar macrophages obtained from active chronic eosinophilic pneumonia are able to stimulate eosinophil chemiluminescence [148].

\section{Endothelial cells}

Since endothelial cells are located strategically at the interface between circulating blood cells and tissue, interaction with eosinophils are of particular interest with respect to transmigration from the circulation into the tissue. The significance of endothelial cells for eosinophils relates to their ability to release cytokines [266-268], PAF [269, 270], the co-operative synthesis of other lipid mediators [271], and the expression of adhesion molecules (for review see [272]). At the same time, endothelial cells represent a target for the action of these mediators [273].

Although the mechanisms facilitating transmigration of leucocytes are not yet completely understood, increasing evidence suggests that adhesion molecules expressed both on native and activated endothelial cells, as well as leucocytes, play a crucial role in orchestrating this process. For eosinophils, a number of adhesion molecules of different families, including leucocyte integrins, the selectins, members of the immunoglobulin family, and certain carbohydrates, have been demonstrated to mediate the interaction with vascular endothelial cells.

The endothelial cell expresses ICAM-1, ICAM-2, Eselectin (originally called endothelial-leucocyte adhesion molecule-1 (ELAM-1)), P-selectin (also known as GMP140) and vascular cell adhesion molecule-1 (VCAM-1) [274]. ICAM-1, ICAM-2 and VCAM are glycoproteins belonging to the immunoglobulin gene superfamily, while E-selectin and P-selectin are members of the selectin gene superfamily.

Eosinophils, like neutrophils, monocytes and lymphocytes, constitutively or upon activation express adhesion molecules (see also section on Membrane Receptors and Surface Markers), which correspond to those on endothelial cells. For instance, leucocyte function-associated antigen-1 (LFA-1) (CD11a/CD18) or Mac-1 (CD11b/CD18) on eosinophils can bind to ICAM-1 (CD54) and ICAM2 , respectively, on endothelial cells [275-278]. The significance of ICAM receptors could be demonstrated in a primate model of asthma, in which administration of monoclonal antibody to ICAM-1 attenuated airway eosinophilia and hyperresponsiveness [47]. However, in vitro anti-CD18 antibodies only partially inhibited eosinophil adherence to the vascular endothelium induced by PAF [46]. Moreover, in the leucocyte deficiency syndrome, in which there are genetic deficiences in CD18 and impairments in the abilities of neutrophils to emigrate from the vasculature into sites of inflammation, both lymphocytes and eosinophils can be found in inflammatory lesions [279], indicating that these two cell types facilitate mechanisms of adherence independent of CD18.

Among the non-CD18-dependent pathways, the interaction between E-selectin (ELAM-1) on activated endothelial cells and sialoglycoproteins on eosinophils may be of biological relevance [275-277]. In addition, eosinophils, like neutrophils and mononuclear cells, express L-selectin (also known as lectin cell adhesion molecule-1 (LEC.CAM1), lectin adhesion molecule-1 (LECAM-1), leucocyte adhesion molecule-1 (LAM-1), Mel-14, Leu8 or TQ1) which binds to sialoglycoproteins (glycine cell adhesion molecule (GlyCAM)) on endothelial cells and which is involved in the initial phase of adherence and later shed from the cell surface $[35,276,280]$. However, as for CD18-dependent pathways, adhesive mechanisms involving selectins are not selective. For instance, administration of anti-E-selectin monoclonal antibody in the primate model also blocked neutrophil accumulation in acute antigen-elicited airway inflammation [281].

Recent data suggest that endothelial cells and eosinophils may interact via a more selective mechanism. Both normal and activated eosinophils, but not neutrophils, express VLA-4 [43, 144, 275-277, 282]. VLA-4 is a $\beta 1$-integrin and binds to VCAM-1 as well as to fibronectin on endothelial cells [283]. Blockade of both CD18 and VLA-4 integrin-mediated pathways abolished eosinophil adherence to TNF- $\alpha$ activated endothelia cells [277], whereas a combination of antibodies towards ICAM-1, VCAM-1 
and E-selectin caused only partial inhibition [276, 277]. Since VCAM-1 also facilitates the adherence of lymphocytes and monocytes, but not neutrophils, the interaction between VCAM-1 and VLA-4 may represent an important specific mechanism for the concomitant recruitment of eosinophils and mononuclear leucocytes, into sites of allergic or other immunological reactions.

This conclusion was further supported by findings which demonstrated that VCAM-1 expression on endothelial cells is increased by IL-4, either alone [144] or in concert with TNF or IL-5 [284-286]. In addition, IL-4, which is also involved in the regulation of $\mathrm{IgE}$ synthesis, induced a VLA-4/VCAM-1-dependent adherence of eosinophils and basophils to endothelium, but not neutrophils [144]. In limited studies, augmented expression of endothelial VCAM-1, E-selectin, and ICAM-1 have been found in tissue sites of late-phase reactions [278, 286], and other tissue eosinophilia-related reactions [287, 288].

\section{Epithelial cells}

Eosinophils adhere to and transmigrate through epithelial barriers in asthma to reach the bronchoalveolar space $[289,290]$. In addition to its function as a surface protector and cover, epithelial tissue represents a metabolically active secreting tissue, which may actively interact with inflammatory cells, such as eosinophils. Human airway epithelial cells produce GM-CSF [291-293] as well as PAF, $\mathrm{PGE}_{2}, \mathrm{PGF}_{2 \mathrm{a}}$, [294] and 15-lipoxygenase pathwayderived eicosanoids [295], which may influence eosinophil function after arrival in the bronchoalveolar space. This function, however, may itself represent a target for anti-inflammatory drugs, such as corticosteroids [296]. Furthermore, as with vascular endothelial cells, airway epithelium expresses adhesion molecules, such as ICAM1 [297, 298], and adherence of eosinophils to respiratory epithelium can be partially blocked by monoclonal antibody towards ICAM-1 [47].

\section{Platelets}

Since the discovery that platelets bear $\operatorname{IgE}$ receptors and can be activated during IgE-dependent events [299], the platelet is regarded as another accessory cell involved in allergic disease. Platelets can undergo chemotaxis, and phagocytosis and are able to release a number of proinflammatory mediators [300]. Data demonstrating the role of platelets derive from studies which show that, in a rabbit model, platelet depletion using a selective antiplatelet antiserum prevented antigen-induced bronchospasm [300, 301]. In addition, in guinea-pig, depletion of platelets virtually ablated bronchial hyperreactivity and eosinophil infiltration following exposure to PAF [302], indicating that platelets may be involved in eosinophil recruitment. Two potent eosinophil chemoattractants, PAF [173] and RANTES [229], are produced by platelets and may be involved in platelet-dependent eosinophil migration. Further evidence for the role of platelets in allergic inflammation stems from experiments which show that levels of granular platelet products, such as platelet factor-4 (PF-4) and $\beta$-thromboglobulin ( $\beta$-TG), are raised in asthmatics after antigen challenge and correlated with elevations of eosinophil granule products $[303,304]$. On the other hand, eosinophil products, such as MBP and EPO, have been shown to activate platelets [305].

\section{Lymphocytes}

Eosinophils and lymphocytes are recruited concomitantly into inflammatory sites [290, 306-309], suggesting a link between both cell types. The role of lymphocytes in relation to eosinophils is mainly determined by their production and release of cytokines. Lymphocytes are the source of the two most potent eosinophil chemoattractants known to date, LCF [226] and IL-2 [40, 309]. In addition, cytokines of the Th2 subtype, which is predominantly found in eosinophil-related conditions [310, 311], including IL-3, IL-5, and GM-CSF, probably promote eosinophilopoiesis, eosinophil recruitment, prolong eosinophil survival, and enhance eosinophil function [4, 18, 57, $215,216,220,221,228]$. In addition, the products of recruited lymphocytes are likely to affect the function and subsequent recruitment of additional eosinophils and lymphocytes. For instance, IL-4 elaborated by Th2 cells effectively promotes VCAM-1 expression on endothelial cells [284, 285], which would further facilitate both recruitment and activation of eosinophils and lymphocytes (see above).

\section{Fibroblasts}

Several studies have demonstrated that the function, survival and physical properties of eosinophils are influenced ex vivo by incubation with monolayers of murine fibroblasts supplemented with certain cytokines [65]. These conditions not only promoted the survival of eosinophils, but also caused eosinophils to become hypodense and augmented eosinophil effector functions, such as lipid mediator secretion or antibody-dependent cytotoxicity of helminthic larvae. More recently, it has been shown that human lung-derived fibroblasts alone can promote eosinophil survival in vitro and that GM-CSF elaborated by these cells may be responsible for this effect [312].

On the other hand, since tissue fibrosis is associated with certain hypereosinophilic syndromes, it had been argued that eosinophils may produce factors which induce and maintain fibrogenesis. This view is supported by findings which demonstrate that extracts obtained from human and guinea-pig eosinophils release mitogens for fibroblasts [313], and stimulate fibroblast deoxyribonucleic acid (DNA) synthesis [314].

\section{Recruitment of eosinophils}

\section{General mechanisms}

Adhesion of circulating leucocytes to vascular endothelium is a crucial process for effective host defence against infection and injury. In order to accumulate in tissues, 
circulating leucocytes must adhere to the endothelium lining, penetrate the vessel wall, and migrate to the site of tissue irritation. Acute bronchopulmonary inflammation involves a myriad of cellular and humoral mechanisms, which promote increases in vascular permeability, changes in blood flow, mobilization, accumulation and activation of leucocytes, all of which may have some bearing for eosinophils during emigration into tissue. On a cellular level, eosinophil recruitment involves specific and nonspecific adhesive interactions with vascular endothelial cells, penetration of the blood vessel wall, chemotaxis and accumulation at the site of allergic inflammation.

In recent years, several studies have led to a detailed insight into the possible mechanisms underlying eosinophil recruitment from the circulation into the tissue (fig. 5). This process can be divided arbitrarily into a sequence

\section{RANDOM CONTACT}

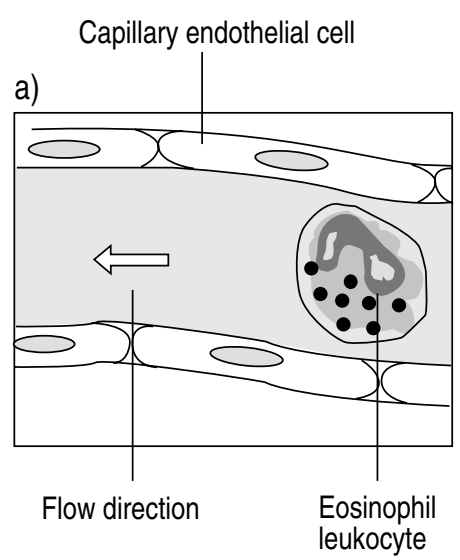

LATE NONSPECIFIC ADHESION (STICKING)

f)

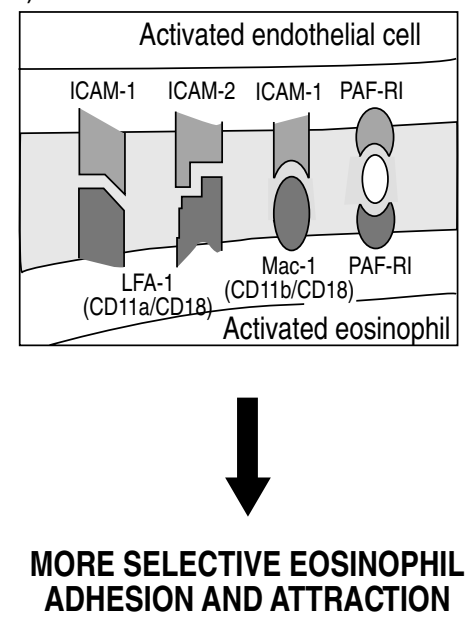

EARLY NONSPECIFIC ADHESION

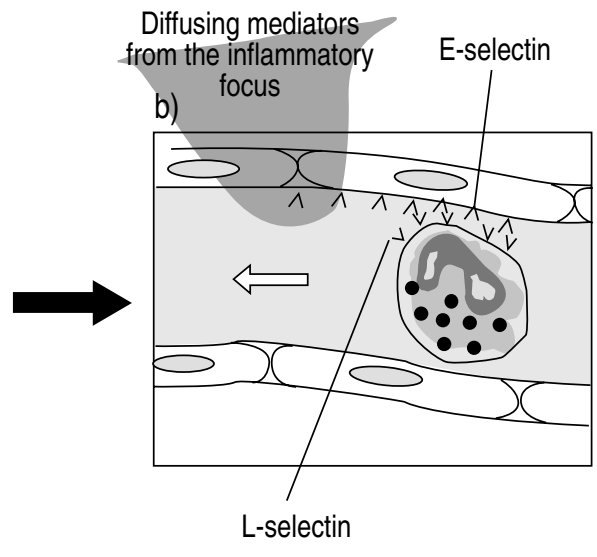

ADHESION MOLECULE EXPRESSION

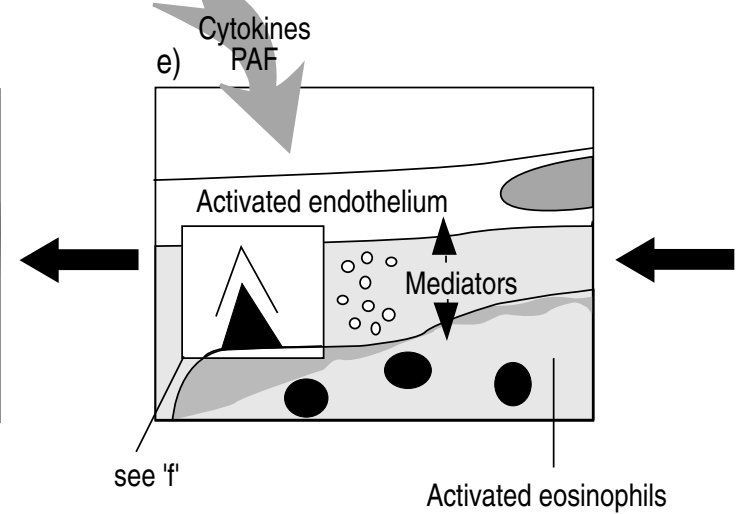

DIAPEDESIS AND

CHEMOTAXIS
ROLLING

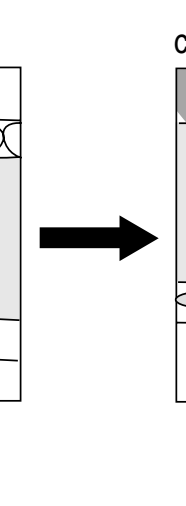

c) Mediators

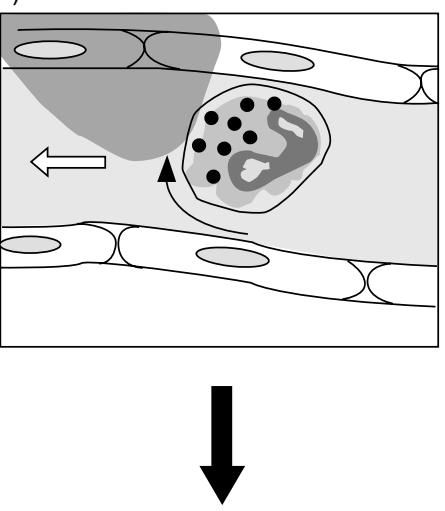

ACTIVATION

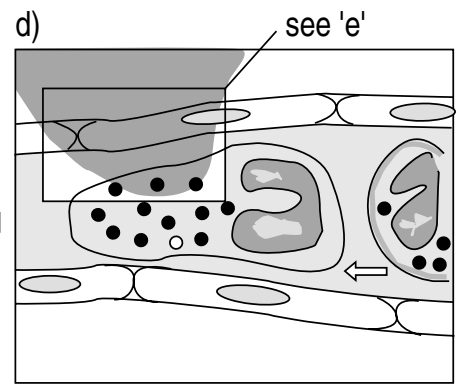

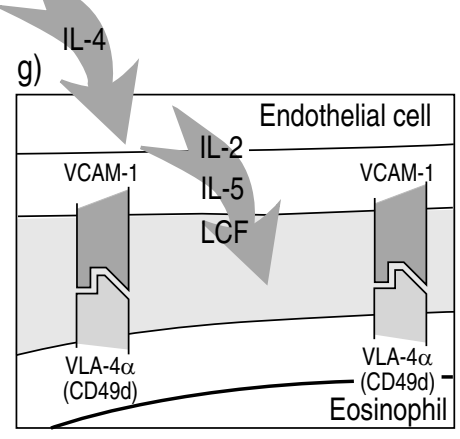

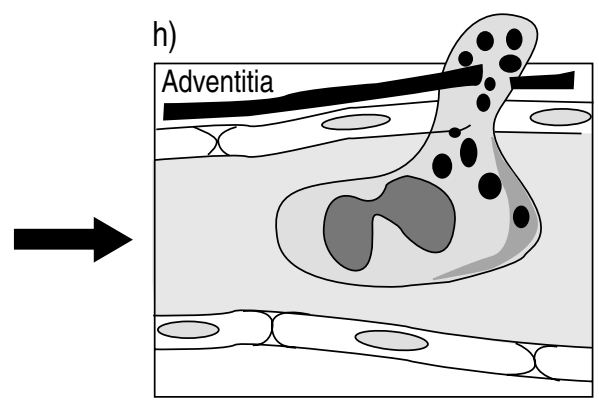

Fig. 5. - Proposed sequence of eosinophil recruitment following immunological activation. IL: interleukin; VCAM-1: vascular cell adhesion molecule; VLA-4: very late activation antigen; LCF: lymphocyte chemoattractant antigen; ICAM: intercellular adhesion molecule; LFA: leucocyte function associated antigen; CD: cluster differentiation. 
of six different, though partly overlapping, stages (fig. 5a-h):

1. Eosinophil emigration may be initiated by random contact of the cell with endothelium, which is most likely to occur in capillary vessels due to their small lumen (fig. 5a).

2. When in the vicinity of an inflammatory site, Lselectin receptors on naive nonactivated eosinophils may interact with locally-activated capillary endothelial cells bearing certain carbohydrate counter structures (possibly E-selectin) [315-317] (fig. 5b). Hence, L-selectin may function as an anchor, mediating an initial reversible adhesion. As a result of this early interaction between eosinophils and endothelial cells and the shear forces due to blood flow, the cells role or skid along the endothelial lining (rolling), thereby slowing the cellular flow possibly to provide the time required for cellular activation by locally-released mediators (fig. 5c).

3. Cytokines diffusing from the inflammatory site and through to the endothelial barrier, as well as cytokines and lipid mediators released by perivascular lymphocytes and macrophages and endothelial cells themselves, may now activate the eosinophil, resulting in both an increase in affinity and expression of adhesion molecules on the eosinophil surface (fig. $5 \mathrm{~d}$ and e). Among the adhesion receptors involved are the $\beta_{1}$-integrin VLA-4 (CDw49d/ CD29), which binds to VCAM-1 on endothelial cells, and $\beta_{2}$-integrin receptors LFA-1 (CD11a/CD18), Mac-1 (CD11b/CD18), and p150.95 (CD11c/CD18), which bind to ICAM-1. These and perhaps other events, in combination with endothelial activation and enhancement or de novo expression of adhesion molecules, are followed by a firm nonspecific (fig. 5f) and a more specific (fig. $5 \mathrm{~g}$ ) eosinophil-endothelial adhesion ("sticking").

4. Chemoattractants (IL-2, IL-5, RANTES, PAF) diffusing from the vicinity of the inflammatory focus may now induce a migratory response in eosinophils (fig. $5 \mathrm{~g}$ ) which subsequently initiates transendothelial migration ("diapedesis"), during which time the leucocyte emigrates between endothelial cells and enters the extracellular space (fig. 5h). In order to facilitate transmigration, the initial adhesive interactions need, in part, to be loosened, which may be achieved by down-regulation or shedding of adhesion receptors. Several recent studies have confirmed that eosinophils shed L-selectin during migration into the bronchial tissue in vivo [35, 36, 43, 318, 319], or across an endothelial cell monolayer in vitro [35].

5. The transmigrated cell now moves along a chemotactic gradient through the inflammatory microenvironment towards the inflammatory focus. In this phase, direct migration may be guided not only by increasing concentrations of chemotactic factors but also through adhesive interactions between eosinophil integrins and tissue extracellular proteins (for review see [272]).

6. As the eosinophil approaches the inflammatory focus, the cell is likely to get exposed to a mixture of increasing concentrations of activating lipid mediators and locally synthesized cytokines, lipid mediators, and neuropeptides. The spectrum and ratio of secreted mediators may determine the degree of eosinophil activation. Since some of the mediators at low concentrations preferentially prime, and at higher concentrations activate, eosinophil effector functioning $[72,320,321]$, it is likely that, during the final approach to the inflammatory focus, the cells increasingly perform their cytotoxic function via release of basic proteins and generation of reactive oxygen species (fig. 6). At the same time, upon arrival at the inflammatory site, i.e. in the airway mucosa, the eosinophil may become immobilized and hyporeactive as a result of cell desensitization due to chemotactic factors, such as PAF [163-168, 318].

7. In the final stage, continued exposure of tissue or intraluminal eosinophils to cytokines released during ongoing inflammation by nearby tissue-dwelling cells

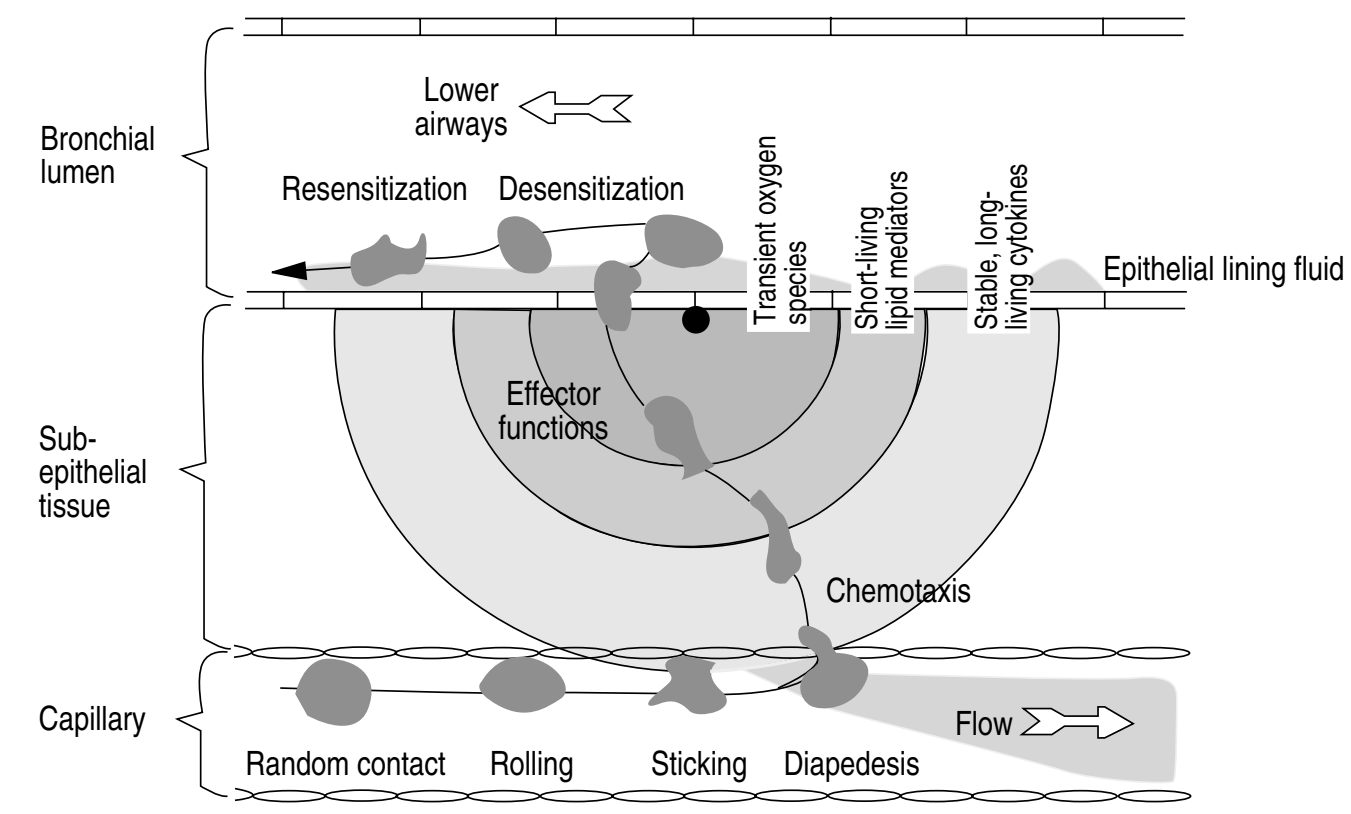

Fig. 6. - Putative sequence of events during eosinophil recruitment from the blood, approach of inflammatory focus and fate of the cells in the setting of asthmatic bronchial inflammation. 
$[138,163]$, endobronchial leucocytes or bronchial epithelial cells, however, may enhance survival and reprime the cell, enabling the eosinophil to regain its proinflammatory properties (paper submitted), namely the release of granule proteins, lipid mediators and reactive oxygen species.

\section{More selective mechanisms}

Since $\beta_{2}$-integrins are expressed on all leucocyte subsets, it is unlikely that they account for the characteristic inflammatory tissue infiltration observed in eosinophilrelated disease. Therefore, in view of possible therapeutic approaches for these diseases, it is of great interest to understand the relative selective mechanism of eosinophil recruitment from the vasculature. To date, two principal mechanisms appear to be operative. Firstly, as outlined above (section on Membrane Receptor), the $\beta_{1}$-integrin VLA-4 (CD49d/CD29) has only been detected on eosinophils, basophils, lymphocytes, monocytes and dentritic cells but not on neutrophils [276, 278, 282-284], suggesting that interaction between VLA-4/VCAM-1 may be involved in more selective eosinophil and basophil recruitment. In addition, it has been shown that IL-4 induces VCAM-1 expression on endothelium, leading to the selective adhesion of human eosinophils and basophils [144, 213]. Hence, VLA-4 expression on eosinophils and binding to endothelial VCAM-1 may account for at least one mechanism by which eosinophils and basophils selectively migrate into inflamed tissue (fig. $5 \mathrm{~g}$ ).

A second possibility for the selective recruitment of eosinophils could be secretion of specific chemoattractants. Possible candidates mediating this mechanism are IL-2, IL-5 and LCF. Whilst IL-5 is only active on eosinophils, IL-2 and LCF also cause concomitant recruitment of CD4+ lymphocytes [322]. However, it is likely that other, as yet unknown, mechanism may be involved.

In view of this rather complex framework of interactions which appear to operate in vivo, one may ask whether it is absolutely necessary to hypothesize an absolutely specific chemoattractant or adhesion molecule for every single cell type. Selective recruitment of eosinophils can be sufficiently explained by the combination of several relatively selective recruitment events generating the conditions leading to selective eosinophil tissue infiltration.

Acknowledgement: The authors gratefully acknowledge
A. Dewar and G. Zeck-Kapp for preparing and providing
the transmission and scanning electron micrograph figures.

\section{References}

1. Clutterbuck EJ, Hirst EMA, Sanderson CJ. Human interleukin-5 (IL-5) regulates the production of eosinophils in human bone marrow cultures: comparison and interaction with IL-1, IL-3, IL-6 and GM-CSF. Blood 1989; 73: 1504-1512.

2. Spry CFJ. Eosinophils. A comprehensive review and guide to the scientific and medical literature. Oxford, New York, Tokyo, Oxford University Press, 1988.

3. Rothenberg ME, Owen WF, Silberstein DS, et al.
Human eosinophils have prolonged survival, enhanced functional properties, and become hypodense when exposed to human interleukin-3. J Clin Invest 1988; 81: 1986-1993.

4. Owen WF, Rothenberg ME, Silberstein DS, et al. Regulation of human eosinophil viability, density, and function by granulocyte/macrophage colony-stimulating factor in the presence of 3 T3 fibroblasts. J Exp Med 1987; 166: 129-141.

5. Miller F, DeHarven E, Palade DE. The structure of eosinophil leukocyte granules in rodents and in man. $J$ Cell Biol 1966; 31: 349-362.

6. Bainton DF, Farquhar M. Segregation and packing of granule enzymes in eosinophil leukocytes. J Cell Biol 1970; 45: 54-73.

7. Dvorak AM, Letourneau L, Login GR, Weller PF, Ackerman SJ. Ultrastructural localization of the CharcotLeyden crystal protein (lysophosphatase) to distinct crystalloid-free granule population in mature human eosinophils. Blood 1988; 72: 150-158.

8. Dvorak AM, Ackerman SJ, Weller PF. Subcellular morphology and biochemistry of eosinophils. In: Harris JR, ed. Blood Cell Biochemistry. Vol. 2. Megakaryocytes, platelets, macrophages and eosinophils. London, Plenum Publishing, 1990; pp. 237-344.

9. Weller PF, Bach D, Austen KF. Human eosinophil lysophosphatase: the sole protein component of CharcotLeyden-crystals. J Immunol 1982; 128: 1346-1349.

10. Weller PF, Goetzl EJ, Austen KF. Identification of human eosinophil lysophosphatase as the constituent of Charcot-Leyden-crystals. Proc Natl Acad Sci USA 1980; 77: 7440-7743.

11. Parmley RT, Spicer SS. Cytochemical and ultrastructural identification of small type granule in human late eosinophils. Lab Invest 1974; 30: 557-567.

12. Schaefer HE, Hubner G, Fischer R. Spezifische Mikrogranula in Eosinophilen. Acta Haematol 1973; 50: 92-104.

13. Komiyama A, Spicer SS. Microendocytosis in eosinophilic leukocytes. J Cell Biol 1975; 64: 622-635.

14. Parmley RT, Spicer SS. Altered tissue eosinophils in Hodgkin's disease. Exp Mol Pathol 1975; 23: 70-82.

15. Weller PF, Dvorak AM. Arachidonic acid incorporation by cytoplasmic lipid bodies of human eosinophils. Blood 1985; 65: 1269-1274.

16. Weller PF, Ackerman SJ, Nickolson-Weller A, Dvorak AM. Cytoplasmic lipid bodies of human neutrophilic leukocytes. Am J Pathol 1989; 135: 947-959.

17. Zucker-Franklin D. Eosinophil function and disorders. Adv Intern Med 1974; 19: 1-26.

18. Kroegel C, Virchow JC Jr, Kortsik C, Matthys C. Cytokines, platelet-activating factor and eosinophils in asthma. Respir Med 1992; 86: 375-389.

19. Hartnell A, Moqbel R, Walsh GM, Bradley B, Kay AB. Fc $\gamma$ and CD11/CD18 receptor expression on normal density and low density human eosinophils. Immunology 1990; 69: 264-270.

20. Kroegel C, Liu MC, Lichtenstein LM, Bochner BS. Antigen-induced eosinophil activation and recruitment in the lower airways. J Allergy Clin Immunol 1991; 87: 303.

21. Hansel TT, Pound JD, Pilling D, et al. Purification of human blood eosinophils by negative selection using immunomagnetic beads. J Immunol Methods 1989; 122: 97-103.

22. Tosi M, Berger M. Functional differences between the $40 \mathrm{kDa}$ and 50 to $70 \mathrm{kDa} \mathrm{IgG} \mathrm{Fc}$ receptors on human neutrophils revealed by elastase treatment and antireceptor antibodies. J Immunol 1988; 141: 2097-2105. 
23. Hartnell A, Kay AB, Wardlaw AJ. INF- $\gamma$ induces expression of FcyRIII (CD16) on human eosinophils. $J$ Immunol 1992; 148: 1471-1478.

24. Capron M, Benveniste J, Braquet P, Capron A. Role of PAF-acether in IgE-dependent activation of eosinophils. In: Braquet $\mathrm{P}$, ed. New Trends in Lipid Mediator Research. Basel, Karger, 1988; Vol. 2: pp. 10-17.

25. Capron M, Tomassini M, Torpier G, Kusnierz JP, MacDonald S, Capron A. Selectivity of mediators released by eosinophils. Int Arch Allergy Clin Immunol 1989; 88: 54-58.

26. Capron M, Capron A, Dessaint JP, Torpier G, Johansson SGO, Prin L. Fc receptors for IgE on human and rat eosinophils. J Immunol 1981; 126: 2087-2092.

27. Capron M, Kusnierz JP, Prin LS. Cytophilic IgE on human blood and tissue eosinophils: detection by flow cytometry. J Immunol 1985; 134: 3013-3018.

28. Grangette C, Gruart V, Ouassi MA, et al. IgE receptor on human eosinophils (FcERII): a comparison with Bcell CD23 and association with adhesion molecule. $J$ Immunol 1989; 143: 3580-3588.

29. Walsh GM, Nagakura T, Iikura Y. Flow-cytometric analysis of increased IgE uptake by normal eosinophils following activation with PAF-acether and other inflammatory mediators. Int Arch Allergy Appl Immunol 1989; 88: 194-196.

30. Capron M, Prin L, Ameisen JC, Capron A. Immunoglobulin receptors on eosinophil leukocytes. In: Kay $\mathrm{AB}$, ed. Eosinophils, Allergy and Asthma. Oxford, Blackwell Scientific Publications, 1989; pp. 11-20.

31. Monteiro RC, Hostoffer RW, Cooper MD, Bonner JR, Gartland GL, Kubagawa H. Definition of immunoglobulin A receptors on eosinophils and their enhanced expression in allergic individuals. J Clin Invest 1993; 92: 1681-1685.

32. Abu-Ghazaleh RI, Fujisawa T, Mestecky J, Kyle RA, Gleich GJ. IgA-induced eosinophil degranulation. $J$ Immunol 1989; 142: 2393-2340.

33. Ottesen EA, Stanley AM, Gelfand JA. Immunoglobulin and complement receptors on human eosinophils and their role in cellular adherence to schistosomules. Am J Trop Med Hyg 1977; 26: 134-139.

34. DeSimone C, Donelli G, Meli D, Rosati F, Sorice F. Human eosinophils and parasitic disease. II. Characterization of two cell fractions isolated at different densities. Clin Exp Immunol 1982; 48: 249-255.

35. Braun R, Virchow JC Jr, Rihs S, et al. Eosinophil surface marker profile in peripheral blood and bronchoalveolar lavages from asthmatic subjects: comparison with in vitro transmigration. J Immunol 1993; (in press).

36. Kroegel C, Braun R, Häfner D, et al. Changes in T-cell subsets and eosinophils in peripheral blood and BAL after segmental allergen provocation. Am Rev Respir Dis 1993; 147: A520.

37. Virchow JC Jr, Braun R, Kortsik $\mathrm{C}$, et al. In vivo activation of T-lymphocytes and expression of surface antigens on eosinophils in blood and BAL in a case of eosinophilic pneumonia. Am Rev Respir Dis 1993; 147: A821.

38. Lucey DR, Nicholson-Weller A, Weller PF. Mature human eosinophils have the capacity to express HLADR. Proc Natl Acad Sci USA 1989; 86: 1348-1351.

39. Plumas J, Gruart V, Aldebert $\mathrm{D}$, et al. Human eosinophils from hypereosinophilic patients spontaneously express the p55 but not the p75 interleukin-2 receptor subunit. Eur J Immunol 1991; 21: 1265-1270.

40. Rand TH, Silberstein DS, Kornfeld H, Weller PF. Human eosinophil express functional interleukin-2 receptors. $J$ Clin Invest 1991; 88: 825-832.
41. Hansel TT, Braunstein JB, Walker C, et al. Sputum eosinophils from asthmatics express ICAM-1 and HLADr. J Clin Exp Immunol 1991; 143: 431.

42. Kroegel C, Walker C, Kortsik C, Matthys C, Blaser K, Virchow JC Jr. In vivo expression of MHC class II protein HLA-DR by bronchoalveolar lavage eosinophils in eosinophilic pneumonia. J Allergy Clin Immunol 1993; 91: 236.

43. Georas SN, Liu MC, Newman W, Beall D, Stealey BA, Bochner BS. Altered adhesion molecule expression and endothelial cell activation accompany the recruitment of human granulocytes to the lung after segmental antigen challenge. Am J Respir Cell Mol Biol 1992; 7: 261269.

44. Nishikawa K, Morii T, Ako H, Hamada K, Saito S, Narita $\mathrm{N}$. In vivo expression of CD69 on lung eosinophils in eosinophilic pneumonia: CD69 as a possible activation marker for eosinophils. J Allergy Clin Immunol 1992; 90: 169-174.

45. Dustin ML, Rothlein R, Bhan AK, Dinarello CA, Springer TA. Induction of IL-1 and interferon- $\gamma$ : tissue distribution, biochemistry, and function of a natural adherence molecule (ICAM-1). J Immunol 1986; 137: 245-253.

46. Lamas AM, Mulroney CM, Schleimer RP. Studies on the adhesive interaction between purified human eosinophils and cultured vascular endothelial cells. J Immunol 1988; 140: $1500-1505$.

47. Wegner CD, Gundel RH, Reilly P, Haynes N, Letts G, Rothlein R. Intercellular adhesion molecule-1 (ICAM1) in the pathogenesis of asthma. Science 1990; 247: 456-458.

48. Ross GD, Cain JA, Lachmann PJ. Membrane complement receptor type three (CR3) has lectin-like properties analogous to bovine conglutinin and functions as a receptor for iC3b. J Immunol 1985; 134: 3307-3315.

49. Fisher E, Capron M, Prin L, Kusnierz JP, Kazatchkine MD. Human eosinophils express CR1 and CR3 complement receptors for cleavage fragments of $\mathrm{C} 3$. Cell Immunol 1986; 97: 297-306.

50. Schleiffenbaum B, Moser, R, Patarroyo M, Fehr J. The cell surface glycoprotein Mac-1 (CD11b/CD18) mediates neutrophil adhesion and modulates degranulation independently of its quantitative cell surface expression. $J$ Immunol 1989; 142: 3537-3545.

51. Huizinga TWJ, Van Kemenade F, Koenderman L, et al. The $40 \mathrm{kDa}$ Fc $\gamma$ receptor (FcRII) on human neutrophils is essential for the IgG-induced respiratory burst and IgGinduced phagocytosis. J Immunol 1989; 142: 2365-2371.

52. Myones BL, Diazell JG, Hogg N, Ross GD. Neutrophil and monocyte cell surface p190,95 has iC3b-receptor (CR4) activity resembling CR3. J Clin Invest 1988; 82: 640-647.

53. Lucey DR, Dorsky DI, Nicholson-Weller A, Weller PF. Human eosinophils express CD4 protein and bind human immunodeficiency virus I gp 120. J Exp Med 1989a; 169: 327-332.

54. Freedman AR, Gibson FM, Fleming SC, Spry CJF, Griffin GE. Human immunodeficiency virus infection of eosinophils in human bone marrow cultures. J Exp Med 1991; 174: $1661-1664$.

55. Rand TH, Cruikshank WW, Center DM, Weller PF. CD4mediated stimulation of human eosinophils: lymphocyte chemoattractant factor and other CD4-binding ligands elicit eosinophil migration. J Exp Med 1991b; 173: $1521-1528$.

56. Anwar ARE, Kay AB. Membrane receptors for IgG and complement $(\mathrm{C} 4, \mathrm{C} 3 \mathrm{~b}$ and $\mathrm{C} 3 \mathrm{~d})$ on human eosinophils 
and neutrophils and their relation to eosinophilia. $J$ Immunol 1977; 119: 976-985.

57. Tai PC, Spry CJF. Enzymes altering the binding capacity of human blood eosinophils for IgG antibody-coated erythrocytes (EA). Clin Exp Immunol 1980; 40: 206-219.

58. Changelian PS, Fearon DT. Tissue-specific phosphorylation of complement receptors CR1 and CR2. J Exp Med 1986; 163: 101-115.

59. Hamada A, Greene BM. C1q enhancement of IgGdependent eosinophil-mediated killing of schistosomula in vitro. J Immunol 1987; 138: 1240-1245.

60. Gerard NP, Hodges MK, Drazen JM, Weller PF, Gerard C. Characterization of a receptor for $\mathrm{C} 5 \mathrm{a}$ anaphylatoxin on human eosinophils. J Biol Chem 1989; 264: 1760-1766.

61. Kay AB, Glass EJ, Salter DM. Leucoattractants enhance complement receptors on human phagocytic cells. Clin Exp Immunol 1979; 38: 294-299.

62. Wright SD, Silverstein SC. Tumor promoting phorbol esters stimulate $\mathrm{C} 3 \mathrm{~b}$ and $\mathrm{C} 3 \mathrm{bi}$ receptor mediated phagocytosis in cultured human monocytes. J Exp Med 1982; 157: $1149-1154$.

63. Bruynzeel PLB, Kok PTM, Hamelink ML, Kijne AM, Verhagen J. Platelet-activating factor induces leukotriene-C4 synthesis by purified human eosinophils. Prostaglandins 1987; 34: 205-214.

64. Kroegel C, Matthys H. Platelet-activating factor-induced human eosinophil activation. Generation and release of cyclooxygenase metabolites in human blood eosinophils from asthmatics. Immunol 1993; 78: 279-285.

65. Owen WF. Cytokine regulation of eosinophil inflammatory disease. Allergy Clin Immunol News 1991; 3: 85-89.

66. Rothenberg ME, Petersen J, Stevens RL, et al. IL-5dependent conversion of normodense human eosinophils to the hypodense phenotype uses 3T3 fibroblasts for enhanced viability, accelerated hypodensity, and sustained antibody-dependent cytotoxicity. J Immunol 1989; 143: 2311-2316.

67. Silberstein DS, Owen WF, Gasson JC, et al. Enhancement of human neutrophil cytotoxicity and leukotriene synthesis by biosynthetic (recombinant) granulocytemacrophage colony-stimulating factor. J Immunol 1986; 137: 3290-3294.

68. Warringa RAJ, Schweizer RC, Maikoe T, Kuijiper PHM, Bruijnzeel PLB, Koenderman L. Modulation of eosinophil chemotaxis by interleukin-5. Am J Respir Cell Mol Biol 1992; 7: 631-636.

69. Takafuji S, Bishoff SC, De Weck A, Dahinden CA. IL3 and IL-5 prime normal human eosinophils to produce leukotriene- $\mathrm{C}_{4}$ in response to soluble agonists. J Immunol 1991; 147: 3855-3861.

70. Fujisawa T, Abu-Ghazaleh R, Kita H, Sanderson CJ, Gleich GJ. Regulatory effect of cytokines on eosinophil degranulation. J Immunol 1990; 144: 642-646.

71. Kroegel C, Warner JA, Giembycz MA, Matthys H, Lichtenstein LM, Barnes PJ. Dual transmembrane signaling mechanisms in eosinophils: evidence for two functionally distinct receptors for platelet activating factor. Int Arch Allergy Appl Immunol 1992; 99: 226-229.

72. Kroegel C, Yukawa T, Westwick J, Barnes PJ. Evidence for two platelet-activating factor receptors on eosinophils: dissociation between PAF-induced intracellular calcium mobilization, degranulation and superoxide anion generation in eosinophils. Biochem Biophys Res Commun 1989; 162: 511-521.

73. Kroegel C. Molecular mechanisms of stimulus-response coupling in human and guinea-pig eosinophils. Transduction pathways utilized by platelet-activating factor and their relationship to effector functions. $\mathrm{PhD}$ thesis, University of London, 1991.

74. Lopez AF, Eglington JM, Gillis D, Park LS, Clark S, Vadas MA. Reciprocal inhibition of binding between interleukin-3 and granulocyte/macrophage colony-stimulating factor to human eosinophils. Proc Natl Acad Sci USA 1989; 86: 7022-7026.

75. Lopez AF, Eglington JM, Lyons $\mathrm{AB}$, et al. Human interleukin-3 inhibits the binding of granulocyte/macrophage colony-stimulating factor and interleukin-5 to eosinophils and strongly enhances their functional activity. J Cell Physiol 1990; 145: 69-75.

76. Migita M, Yamaguchi N, Mita S, et al. Characterization of the human IL-5 receptors on eosinophils. Cell Immunol 1991; 133: 484-493.

77. Ingley E, Young IC. Characterization of the receptor for interleukin-5 on human eosinophils and the myeloid leukemia line HL-60. Blood 1991; 78: 339-345.

78. Lopez AF, Vadas MA, Woodcock JM, et al. Interleukin5 , interleukin-3 and granulocyte/macrophage colonystimulating factor cross compete for binding to cell surface receptors on human eosinophils. J Biol Chem 1991; 266: 24741-24746.

79. Nicola NA, Metcalf D. Subunit promiscutity among hemopoietic growth factor receptors. Cell 1991; 67: 1-9.

80. Gleich GJ, Adolphson CR. The eosinophil leukocyte: structure and function. Adv Immunol 1986; 39: 177-253.

81. Barker RL, Loegering DA, Ten RM, Hamann KJ, Pease LR, Gleich GJ. Eosinophil cationic protein cDNA: comparison with other toxic cationic proteins and ribonucleases. J Immunol 1989; 143: 952-955.

82. Barker RL, Loegering DA, Arakawa KC, Pease LA, Gleich GJ. Cloning and sequence analysis of human gene encoding eosinophil major basic protein. Gene 1990; 86: 285-289.

83. Wasmoen TL, Bell MP, Loegering DA, Gleich GJ, Prendergast FG, McKean DJ. Biochemical and amino acid sequence analysis of human eosinophil granule major basic protein. J Biol Chem 1988; 263: 12559-12563.

84. Rosenberg HF, Ackerman SJ, Tenen DG. Human eosinophil cationic protein: molecular cloning of a cytotoxin and helminthotoxin with ribonuclease activity. $J$ Exp Med 1989; 170: 163-176.

85. McGrogan M, Simonsen C, Scott R. Isolation of a complementary DNA clone encoding a precursor to human eosinophil major basic protein. J Exp Med 1988; 168: 2295-2308.

86. Rosenberg HF, Tenen DG, Ackerman SJ. Molecular cloning of the human eosinophil-derived neurotoxin: a member of the ribonuclease gene family. Proc Natl Acad Sci 1989; 86: 4460-4464.

87. Sakamaki K, Tomonaga M, Tsukui K, Nagata S. Molecular cloning and characterization of a chromsomal gene for human eosinophil peroxidase. J Biol Chem 1989; 264: 16828-16836.

88. Ten RM, Pease LR, McKean DJ, Bell MP, Gleich GJ. Molecular cloning of the human eosinophil peroxidase: evidence for the existence of a peroxidase multigene family. J Exp Med 1989; 169: 1757-1769.

89. Leherer RI, Szklarek D, Barton A, Ganz T, Hamann KJ, Gleich GJ. Anti-bacterial properties of eosinophil major basic protein and eosinophil cationic protein. J Immunol 1989; 142: 4428-4438.

90. Hamann KJ, Barker RL, Loegering DA, Pease LA, Gleich GJ. Sequence of a human eosinophil-derived neurotoxin cDNA identity of deduced amino acid sequence with human nonsecretory ribonuclease. Gene 1989; 83: 161-167. 
91. Gleich GJ, Loegering DA, Bell MP, Checkel JL, Ackermann SJ, McKean DJ. Biochemical and functional similarities between eosinophil-derived neurotoxin and eosinophil cationic protein: homolgy with ribonuclease. Proc Natl Acad Sci USA 1986; 83: 3146-3150.

92. Olsson I, Person A-M, Winqvist I. Biochemical properties of the eosinophil cationic protein and demonstration of its biosynthesis in vivo in marrow cells from patients with an eosinophilia. Blood 1986; 67: 498-503.

93. Gordon MH. Remarks on Hodgkin's disease: a pathogenic agent in the glands, and its application in diagnosis. $\mathrm{Br}$ Med J 1933; I: 641-644.

94. Olson RL, Little C. Purification and some properties of myeloperoxidase and eosinophil peroxidase from human blood. Biochem J 1983; 209: 781-787.

95. Weller PF, Ackerman SJ, Smith JA Eosinophil granule cationic proteins: major basic protein is distinct from the smaller subunit of eosinophil peroxidase. J Leukocyte Biol 1988; 43: 1-4.

96. Jong EC, Klebanoff SJ. Eosinophil-mediated tumor cell cytotoxicity: role of the peroxidase system. J Immunol 1980; 124: 1949-1953.

97. Jong EC, Henderson WR, Klebanoff SJ. Bactericidal activity of eosinophil peroxidase. J Immunol 1980; 124: 1378-1382.

98. Nogueira NM, Klebanoff SJ, Cohn ZA. T. cruzi: sensitization to macrophage killing by eosinophil peroxidase. J Immunol 1980; 124: 1949-1953.

99. Jong EC, Mahmoud AAF, Klebanoff SJ. Peroxidasemediated toxicity to schistosomula of Schistosoma mansoni. J Immunol 1981; 126: 468.

100. Kita H, Ohnishi T, Okubo Y, Weiler D, Abrams JS, Gleich GJ. Granulocyte/macrophage colony-stimulating factor and interleukin-3 release from human peripheral blood eosinophils and neutrophils. J Exp Med 1991; 174: 745-748.

101. Moqbel R, Hamid Q, Ying S, et al. Expression of mRNA and immunoreactivity for the granulocyte/macrophage colony-stimulating factor in activated human eosinophils. J Exp Med 1991; 174: 749-752.

102. Wong TW, Weller PF, Galli SJ, et al. Human eosinophils express transforming growth factor- $\alpha$. J Exp Med 1990; 172: 673-681.

103. Ohno I, Lea RG, Flanders KC et al. Eosinophils in chronically inflamed human upper airway tissue express transforming growth factor- $\beta 1$ gene (TGF- $\beta 1)$. J Clin Invest 1992; 89: 1662-1668.

104. Dechatelet LR, Shirley MR, McPhail LC, Huntley CC, Muss HB, Bass DA. Oxidative metabolism of human eosinophils. Blood 1977; 50: 525-535.

105. Klebanoff SJ, Durack DT, Rosen H, Clark RA. Functional studies on human peritoneal eosinophils. Infect Immunol 1977; 17: 167-173.

106. Tauber AI, Goetzl EJ, Babior BM. Unique characteristics of superoxide production by human eosinophils in eosinophilic states. Inflammation 1979; 3: 261-269.

107. Baehner RL, Johnston RB Jr. Metabolic and bactericidal activities of human eosinophils. Br J Haematol 1971; 20: 277-285.

108. Kazura JW, Fanning MM, Blumer JL, Mahmoud AA. Role of cell-generated hydrogen peroxide in granulocytemediated killing of schistosomula of Schistosoma mansoni in vitro. J Clin. Invest 1981; 67: 93-192.

109. Mickenberg ID, Root RK, Wolff SM. Bactericidal and metabolic properties of human eosinophils. Blood 1972; 39: $67-80$.

110. Kroegel C, Yukawa T, Dent G, Venge P, Chung KF,
Barnes PJ. Stimulation of degranulation from human eosinophils by platelet activating factor. J Immunol 1989; 142: 3518-3526.

111. Weiss SJ, Test ST, Eckmann Roos D, Regiani S. Brominating oxidants generated by human eosinophils. Science 1986; 234: 200-203.

112. Kanofsky JR, Hoogland H, Wever R, Weiss SI. Singlet oxygen production by human eosinophils. J Biol Chem 1988; 263: 9692-9696.

113. Yamashita T, Someya A, Hara E. Response of superoxide anion production by guinea-pig eosinophils to various soluble stimuli: comparison to neutrophils. Arch Biochem Biophys 1985; 241: 447-452.

114. Segal AW, Garcia R, Goldstone, AH, Jones OTG. Cytochrome b245 of neutrophils is also present in human monocytes, macrophages and eosinophils. Biochem $J$ 1981; 196: 363-367.

115. Kauffman HF, van der Belt B, de Monchy JG, Boelens $\mathrm{H}$, Koeter $\mathrm{GH}$, de Vries K. Leukotriene $\mathrm{C}_{4}$ production by normal density and low-density eosinophils of atopic individuals and other patients with eosinophilia. J Allergy Clin Immunol 1987; 79: 611-619.

116. Tamura N, Agrawal DK, Suiama FA, Townley RG. Effects of platelet-activating factor on the chemotaxis of normodense eosinophils from normal subjects. Biochem Biophys Res Commun 1987; 142: 638-644.

117. Burke LA, Crea AEG, Wikinson JRW, Arm JP, Spur $\mathrm{BW}$, Lee TH. Comparison of the generation of plateletactivating factor and leukotriene $\mathrm{C} 4$ in human eosinophils stimulated by unopsonized zymosan and by calcium ionophore A23187: the effect of nedocromil sodium. $J$ Allergy Clin Immunol 1990; 85: 26-35.

118. Hubscher T. Role of the eosinophil in allergic response. II. Release of prostaglandins from human eosinophilic leukocytes. J Immunol 1975; 114: 1389-1394.

119. Giembycz MA, Kroegel C, Barnes PJ. Stimulation of the cyclo-oxygenase pathway in eosinophils by plateletactivating factor. Release of thromboxane- $\mathrm{A}_{2}$ and prostaglandine $\mathrm{E}$ and their effects on eosinophil function. J Immunol 1990; 144: 3489-3497.

120. Owen WF, Soberman RJ, Yoshimoto T, Sheffer AL, Lewis RA, Austen KF. Synthesis and release of leukotriene C4 by human eosinophils. J Immunol 1988; 138: 532 538.

121. Foegh ML, Maddox YT, Ramwell PW. Human peritoneal eosinophils and formation of arachidonate cyclo-oxygenase products. Scand J Immunol 1986; 23: 599-603.

122. Morley J, Bray MA, Jones RW, Nugteren DH, van Dorp D. Prostaglandin and thromboxane production by human and guinea-pig macrophages and leukocytes. Prostaglandins 1979; 17: 729-746.

123. Kroegel C, Hubbard HW, Lichtenstein LM. Spectrum of prostanoid generation by human blood eosinophils stimulated with platelet-activating factor. Eur Respir $J$ 1990; 3: 347s.

124. Lee TC, Malone B, Wasserman SI, Fitzgerald V, Snyder F. Activities that metabolize platelet-activating factor (1alkyl-2-acetyl-sn-glycero-3-phosphocholine) in neutrophils and eosinophils from humans and the effect of a calcium ionophore. Biophys Biochem Res Commun 1982; 105: 1303-1310.

125. Lee T, Lenihan DJ, Malone B, Roddy LL, Wasserman SI. Increased biosynthesis of platelet-activating factor in activated human eosinophils. J Biol Chem 1984; 259: 5526-5530.

126. Oda M, Satouchi K, Ikeda I, Sakakura M, Yasunga K, Saito K. The presence of platelet-activating factor 
associated with eosinophil and/or neutrophil accumulation in the pleural fluids. Am Rev Respir Dis 1990; 141: 1469-1473.

127. Johnson HM, Torres BA. Immunoregulatory properties of neuroendocrine peptide hormones. Prog Allergy 1988; 43: 37-67.

128. Weinstock JV, Blum A. Tachykinin production by granuloma eosinophils in murine Schistosomiasis mansoni. J Immunol 1989; 142: 3256-3261.

129. Weinstock JV, Blum A. Detection of vasoactive intestinal petide and localization of its mRNA within granulomas of murine schistosomiasis. Cell Immunol 1990; 125: 291-300.

130. Weinstock JV, Blum A, Walder J, Walder R. Eosinophils from granulomas in murine schistosomiasis mansoni produce substance P. J Immunol 1988; 141: 961-966.

131. Kroegel C, Giembycz MA, Barnes PJ. Characterization of eosinophil cell activation by peptides. Differential effects of substance P, melittin and fMet-Leu-Phe. $J$ Immunol 1990; 145: 2581-2587.

132. Chanez P, Bousquet J, Couret I, et al. Increased numbers of hypodense alveolar macrophages in patients with bronchial asthma. Am Rev Respir Dis 1991; 144: 923-930.

133. Miyagawa H, Okada C, Sugiyama H, et al. Density distribution and density conversion of neutrophils in allergic subjects. Int Arch Allergy Appl Immunol 1990; 93: 813.

134. Pemper SA, Barnes KC, Kinkade JM, et al. Density heterogeneity of neutrophil polymorphonuclear leukocytes: gradient fractionation and relationship to chemotaxis. Blood 1983; 61: 1105-1115.

135. Kroegel C, Dewar A, Yukawa T, Chung KF, Barnes PJ. Ultrastructural characterization of platelet-activating factorstimulated human eosinophils from subjects with asthma. Clin Sci 1993; 84: 391-399.

136. Yukawa T, Kroegel C, Evans P, Fukuda T, Chung KF, Barnes PJ. Density heterogeneity of eosinophils: induction of hypodense eosinophils by platetet-activating factor. Immunology 1989; 68: 140-143.

137. Walker C, Kaegi MK, Braun P, Blaser K. Activated Tcell changes and eosinophilia in bronchoalveolar lavages from subjects with asthma correlated with disease severity. J Allergy Clin Immunol 1991b; 88: 935-942.

138. Kroegel C, Liu M, Hubbard WM, Lichtenstein LM, Bochner BS. Blood and bronchoalveolar eosinophils in allergic subjects following segmental antigen challenge. Surface phenotype, density heterogeneity and prostanoid production. J Allergy Clin Immunol 1994; (in press).

139. Hansel TT, Braunstein JB, Walker C, et al. Sputum eosinophils from asthmatics express ICAM-1 and HLADR. J Clin Exp Immunol 1991; 143: A431.

140. Kroegel C, Braun R, Häfner D, et al. Phenotype of eosinophils in disease. Comparison of blood and BAL eosinophils in allergic asthma and eosinophilic pneumonia. Eur Respir J 1993; 6: 475s.

141. Neeley SP, Hamann KJ, White SR, Baranowski SL, Burch RA, Leff AR. Selective regulation of surface adhesion molecules Mac-1, L-selectin and VLA-4 on human eosinophils and neutrophils. Am J Respir Cell Mol Biol 1993; 8: 633-639.

142. Walsh CM, Hartnell A, Wardlaw AJ, Kurihara K, Sanderson CJ, Kay AB. IL-5 enhances the in vitro adhesion of human eosinophils, but not neutrophils, in a leucocyte integrin (CD11/18)-dependent manner. Immunology 1990; 71: $258-265$.

143. Kyan-Aung U, Haskar DO, Lee TK. Vascular cell adhesion molecule-1 and eosinophil adhesion to cultured human umbilical vein endothelial cells in vitro. Am J Respir Cell Mol Biol 1991; 5: 445-450.

144. Schleimer RP, Sterbinsky SA, Kaiser S, et al. IL-4 induces adherence of human eosinophils and basophils but not neutrophils to endothelium: association with expression of VCAM-1. J Immunol 1992; 148: 1086-1092.

145. Fukuda T, Gleich GJ. Heterogeneity in eosinophils. $J$ Allergy Clin Immunol 1989; 83: 369-373.

146. Fukuda T, Dunnette SL, Reed CE, Ackerman SJ, Peters MS, Gleich GJ. Increased numbers of hypodense eosinophils in the blood of patients with bronchial asthma. J Allergy Clin Immunol 1985; 132: 981-985.

147. Shult PA, Lega M, Jadidi S, et al. The presence of hypodense eosinophils and diminished chemiluminescence response in asthma. J Allergy Clin Immunol 1988; 81: 429-435.

148. Prin L, Capron M, Gosset P, et al. Eosinophilic lung disease: immunological studies of blood and alveolar eosinophils. Clin Exp Immunol 1986; 63: 249-256.

149. Frick WE, Sedgwick JB, Busse WW. Hypodense eosinophils in allergic rhinitis. J Allergy Clin Immunol 1988; 82: 119-125.

150. Frick WE, Sedwick JB, Busse WW. The appearence of hypodense eosinophils in antigen-dependent late phase asthma. Am Rev Respir Dis 1989; 139: 1401-1406.

151. Kloprogge E, DeLeeuw AJ, DeMonchy JGR, Kauffman HF. Hypodense eosinophilic granulocytes in normal individuals and patients with asthma: generation of hypodense cell populations in vitro. J Allergy Clin Immunol 1989; 83: 393-400.

152. Bochner B, Friedman B, Krishnaswami G, Schleimer RP, Lichtenstein LM, Kroegel C. Episodic eosinophiliamyalgia-like syndrome in a patient without L-tryptophan use. Association with eosinophil activation and increased serum levels of granulocyte-macrophage colony-stimulating factor. J Allergy Clin Immunol 1991; 88: 629-639.

153. Sedgwick JB, Calhoun WJ, Gleich GJ, et al. Immediate and late airway response of allergic rhinitis patients to segmental antigen challenge. Characterisation or eosinophil and mast cell mediators. Am Rev Respir Dis 1991; 144: 1274-1281.

154. Kroegel C, Matthys H, Costabel U. Morphology and density features of eosinophil leukocytes in eosinophilic pneumonia. A case report. Clin Invest 1992; 70: 447-453.

155. Prin L, Capron M, Tonnel AB, Bletry O, Capron A. Heterogeneity of human peripheral blood eosinophils: variability in cell density and cytotoxic ability in relation to the level and the origin of hypereosinophilia. Int Arch Allergy Appl Immunol 1983; 72: 336-346.

156. Khalife J, Capron M, Cesbron JY, et al. Role of specific IgE antibodies in peroxidase (EPO) release from human eosinophils. J Immunol 1986; 137: 1659-1664.

157. Capron M, Spiegelberg HC, Prin L, et al. Role of IgE receptor in effector function of human eosinophils. $J$ Immunol 1984; 132: 462-468.

158. Bass DA, Grover WH, Lewis JC, Szejda P, DeChatelet LR, McCall CE. Comparison of human eosinophils from normals and patients with eosinophilia. J Clin Invest 1980; 66: 1265-1271.

159. Kajita T, Yui Y, Mita $\mathrm{H}$, et al. Release of leukotriene $\mathrm{C}_{4}$ from human eosinophils and its relation to the cell density. Int Arch Allergy Appl Immunol 1985; 78: 406-410.

160. Shaw RJ, Cromwell O, Kay AB. Preferential generation of leukotriene $\mathrm{C} 4$ by human eosinophils. Clin Exp Immunol 1984; 56: 716-722.

161. Winqvist I, Olofsson WT, Persson AM, Hallberg T. Altered density, metabolism, and surface receptors of 
eosinophils in eosinophilia. Immunology 1982; 47: 531-539.

162. Cromwell O, Wardlaw AJ, Champion A, Moqbel R, Osel $\mathrm{D}$, Kay AB. IgG-dependent generation of plateletactivating factor by normal and low density human eosinophils. J Immunol 1990; 145: 3862-3868.

163. Kroegel C, Virchow JC Jr, Matthys H. Cell biology and effector functions of the eosinophil leucocyte in bronchial asthma. In: Kummer F, ed. Asthma: Immunopathologie und Immunotherapie. London, Berlin, New York, Springer Verlag, 1993; pp. 34-54.

164. Lui MC, Hubbard WC, Proud D. Immediate and late inflammatory responses to ragweed antigen challenge of the peripheral airways in asthmatics: cellular, mediator and permeability changes. Am Rev Respir Dis 1991; 144: $51-58$.

165. Wenzel SE, Westcott JY, Smith HR, Larson GL. Spectrum of prostanoid release after bronchoalveolar allergen challenge in atopic asthmatics and in control groups. Am Rev Respir Dis 1989; 139: 450-457.

166. Virchow JC Jr, Walker C, Häfner D, et al. Activated $\mathrm{T}$-cells and cytokine pattern in BAL, pre- and postsegmental allergen challenge in allergic asthma. Am Rev Respir Dis 1993; (in press).

167. Kroegel C, Pleass R, Yukawa T, Chung KF, Westwick J, Barnes PJ. Characterization of platelet-activating factorinduced elevation of cytosolic free calcium concentration in eosinophils. FEBS Lett 1989; 243: 41-46.

168. Koh YY, Duouis R, Albertine KH, Fish JE, Peters SP. Characterization of inflammatory cells recruited to the airways of atopic subjects after local antigen challenge. II. Neutrophils recruited to the lung are desensitized to leukotriene $\mathrm{B}_{4}$. Am Rev Respir Dis 1991; 143: 83.

169. Henderson WR, Chi EY, Jorg A, Klebanoff SJ. Horse eosinophil degranulation induced by the ionophore A23187. Ultrastructure and role of phospholipase $\mathrm{A}_{2}$. Am J Pathol 1983; 111: 341-349.

170. Basran P, Pincus SH. Oxidative requirements for degranulation of human peripheral blood eosinophils. Infect Immunity 1988; 56: 1907-1911.

171. Goetzl EJ, Austen KF. Eosinophil chemotactic factor of anaphylaxis (ECF-A): cellular origin, structure and function. Monogr Allergy 1977; 12: 189-197.

172. Bryant DH, Kay AB. Cutaneous eosinophil accumulation in atopic and nonatopic individuals: the effect of an ECF-A tetrapeptide and histamine. Clin Allergy 1977; 7: 211-217.

173. Wardlaw AJ, Moqbel R, Cromwell O, Kay AB. Plateletactivating factor: a potent chemotactic and chemokinetic factor for human eosinophils. J Clin Invest 1986; 78 : 1701-1706.

174. Kroegel C, Konig W, Mollay C, Kreil G. Generation of the eosinophil chemotactic factor (ECF) from various cell types by melittin. Molec Immunol 1981; 18: 227236.

175. Barnes PJ, Chung KF, Page CP. Inflammatory mediators and asthma. Pharmacol Rev 1988; 40: 49-84.

176. Barnes PJ, Kroegel C, Yukawa T, Dent G, Chung KF. Pharmacology of eosinophils. In: Kay AB, ed. Eosinophils, Allergy and Asthma. Oxford, London, Edinburgh, Boston, Melbourne, Blackwell Scientific Publications. 1990; pp. 144-158.

177. Denjean A, Arnoux B, Masse R. Acute effect of intratracheal administration of platelet-activating factor in baboons. $J$ Appl Physiol: Respirat Environ Exercise Physiol 1983; 55: 93.

178. Vargaftig BB, Lefort J, Chignard M, Benvensite J. Platelet- activating factor induces a platelet-dependent bronchoconstriction unrelated to the formation of prostaglandin derivates. Eur J Pharmacol 1980; 65: 185-192.

179. O'Donnell SR, Barrett CJK. Microvascular leakage to platelet-activating factor in guinea-pig trachea and bronchi. Eur J Pharmacol 1987; 138: 385-396.

180. Evans TW, Chung KF, Rogers DF, Barnes PJ. Effect of platelet-activating factor on airway vascular permeability: possible mechanisms. J Appl Physiol 1987; 63: 479-489.

181. Patterson R, Bernstein PR, Harris KE. Airway responses to sequential challenges with platelet-activating factor and leukotriene $\mathrm{D}_{4}$ in Rhesus monkeys. J Lab Clin Med 1984; 104: 340-345.

182. Cuss FM, Dixon CMS, Barnes PJ. Effects of inhaled platelet-activating factor on pulmonary function and bronchial responsiveness in man. Lancet 1986; ii: 189-192.

183. Barnes PJ, Chung KF, Page CP. Platelet-activating factor as a mediator of allergic disease. J Allergy Clin Immunol 1988; 81: 919-934.

184. Page CP, Morley J. Evidence favoring PAF rather than leukotrienes in the pathogenesis of asthma. Pharmacol Res Commun 1986; 18 (Suppl.): 217-237.

185. Page CP. The role of platelet-activating factor in asthma. J Allergy Clin Immunol 1988; 81: 144-152.

186. Morita E, Schröder J-M, Christophers E. Chemotactic responsiveness of eosinophils isolated from patients with inflammatory skin disease. J Dermatol 1989; 16: 348-351.

187. Kroegel C, Yukawa T, Dent G, Venge P, Chung KF, Barnes PJ. Stimulation of degranulation from human eosinophils by platelet-activating factor. J Immunol 1989; 142: 518-526.

188. Sigal CE, Valone FH, Holtzman MJ, Goetzl EJ. Preferential human eosinophil chemotactic activity of the plateletactivating factor (1-0-alkyl-2-acetyl-sn-glycerol-3phosphatidylcholine). J Clin Immunol 1987; 7: 179-184.

189. Henocq E, Vargaftig BB. Skin eosinophilia in atopic patients. J Allergy Clin Immunol 1988; 81: 691-695.

190. Lellouch-Tubina A, Lefort J, Pirotzky H, Vargaftig BB, Pfister A. Ultrastructural evidence for extravascular platelet recruitment in the lung upon intravenous injection of platelet-activating factor (PAF-acether) to guinea-pigs. Br J Exp Pathol 1985; 66: 345-355.

191. Lellouch-Tubiana A, Lefort J, Pfister A, Vargaftig BB. Interactions between granulocytes and platelets with the guinea-pig lung in passive anaphylactic shock. Correlations with PAF-acether-induced lesions. Int Arch Allergy Appl Immunol 1987; 83: 198-205.

192. Kimani G, Tonnesen MG, Henson PM Stimulation of eosinophil adherence to human vascular endothelial cells in vitro by platelet-activating factor. J Immunol 1988; 140: 3161-3166.

193. Morland CM, Wilson SJ, Holgate ST, Roche WR. Selective eosinophil leukocyte recruitment by transendothelial migration and not by leukocyte-endothelial cell adhesion. Am J Respir Cell Mol Biol 1992; 6: 557-566.

194. Casale TB, Erger RA, Little MM. Platelet-activating factor-induced human eosinophil transendothelial migration: evidence for a dynamic role of the endothelium. Am J Respir Cell Mol Biol 1993; 8: 77-82.

195. MacDonald AJ, Moqbel R, Wardlaw AJ, Kay AB. Plateletactivating factor (PAF-acether) enhances eosinophil cytotoxicity in vitro. J Allergy Clin Immunol 1986; 77: 227.

196. Zeck-Kapp G, Kroegel C, Krutmann J, Kapp A. Complement protein C5a and human eosinophil activation. Evidence for different morphological and functional responses to $\mathrm{C} 5 \mathrm{a}$, platelet-activation factor and interleukin5. Blood 1994; (in press). 
197. Kroegel C, Yukawa T, Dent G, Chanez P, Chung KF, Barnes PJ. Platelet-activating factor induces eosinophil peroxidase release from purified human eosinophils. Immunology 1988; 64: 559-562.

198. Townley RG, Okada C, Miyagawa H, et al. The effect of cetirizine on eosinophil chemotaxis and release of eosinophil peroxidase (EPO) in human allergic subjects. J Allergy Clin Immunol 1991; 87: 281.

199. Koenderman L, Kuijpers TW, Blom M, Tool AT, Roos D, Verhoeven AJ. Characteristics of CR3-mediated aggregation in human eosinophils: effects of priming by platelet-activating factor. J Allergy Clin Immunol 1991; 87: 947-954.

200. Bach MK, Bashler JR. fMLP is a potent activator of guinea-pig eosinophils but its activity is dependent on the prior overnight in vitro culture of the cells (facilitation). Immunol 1992; 75: 680-687.

201. Yazdanbakhsh M, Tai PC, Spry CJF, Gleich GJ, Roos D. Synergism between eosinophil cationic protein and oxygen metabolites in killing of schistosomula of Schistosoma mansoni. J Immunol 1987; 138: 3443-3447.

202. Palmblad J, Gyllenhammar H, Lindgren JA, Malmsten CL. Effects of leukotrienes and f-met-leu-phe on oxidative metabolism of neutrophils and eosinophils. J Immunol 1984; 132: 3041-3045.

203. Henson PM. The adherence of leukocytes and platelets induced by fixed IgG or complement. Immunology 1969; 16: 107-121.

204. Fleit HB, Wright SD, Durie CJ, Valinsky JE, Unkeless JC. Ontogeny of Fc receptors and complement receptor (CR3) during human myeloid differentiation. J Clin Invest 1984; 73: 516-525.

205. Anderson AL, Looney RJ. Human leukocyte Fc receptors. Immunol Today 1986; 7: 264-267.

206. Thorne KJ, Free J, Franks D, Oliver RC. The mechanism of Fc-mediated interaction of eosinophils with immobilized immune complexes. II. Identification of two membrane proteins, modified by the interaction. J Cell Sci 1982; 56: 357-369.

207. Ishikawa $\mathrm{T}$, Wicher $\mathrm{K}$, Arbesman $\mathrm{CE}$ In vitro and in vivo studies on uptake of antigen-antibody complexes by eosinophils. Int Arch Allergy Appl Immunol 1974; 46: 230-248.

208. Ogawa H, Kunkel SL, Fantone JC, Ward PA. Digestion of the fifth component of complement by eosinophil lysosomal enzymes: production of eosinophil specific chemotactic activity. Virchows Arch (Cell Pathol) 1981; 38: 149-157.

209. Yazdanbakhsh M, Tai PC, Spry CJF, Gleich GJ, Roos D. Synergism between eosinophil cationic protein and oxygen metabolites in killing of schistosomula of Schistosoma mansoni. J Immunol 1987; 138: 3443-3447.

210. Henderson WR, Harley JB, Fauci AS, Chi EY. Hypereosinophilic syndrome human eosinophil degranulation induced by soluble and particulate stimuli. Br J Haematol 1988; 69: 13-21.

211. Kemen P, Wymann MP, Von Tscharner V, et al. Shape change, exocytosis, and cytosolic free calcium changes in stimulated human eosinophils. J Clin Invest 1991; 87: 2012-2017.

212. Kroegel C, Chilvers ER, Giembycz MA, Challiss RAJ, Barnes PJ. Platelet-activating factor stimulates a rapid accumulation of D-myo-inositol(1,4,5)-trisphosphate in guinea-pig eosinophils. Relationship to intracellular calcium mobilization and degranulation. J Allergy Clin Immunol 1991; 88: 114-124.

213. Schleimer RP, Benenti SV, Friedman B, Bochner BS.
Do cytokines play a role in leukocyte recruitment and activation in the lungs?. Am Rev Respir Dis 1991; 143: 1169-1174.

214. Howell CJ, Pujol JL, Crea AEG, et al. Identification of an alveolar macrophage-derived activity in bronchial asthma that enhances leukotriene $\mathrm{C}_{4}$ generation by human eosinophils stimulated by ionophore A23187 as a granulocyte-macrophage colony-stimulating factor. $\mathrm{Am}$ Rev Respir Dis 1989; 140: 1340-1347.

215. Yamaguchi Y, Hayashi Y, Sugama Y, et al. Highly purified murine interleukin-5 stimulates eosinophil function and prolongs survival. IL-5 as an eosinophil chemotactic factor. J Exp Med 1988; 167: 1737-1742.

216. Fujisawa T, Abu-Ghazaleh R, Kita H, Sanderson CJ, Gleich CJ. Regulatory effect of cytokines on eosinophil degranulation. J Immunol 1990; 144: 642-646.

217. Walsh GM, Hartnell A, Wardlaw AJ, Kurihara K, Sanderson $\mathrm{CJ}$, Kay AB. IL-5 enhances the in vitro adhesion of human eosinophils but not neutrophils, in a leukocyte integrin (CD11/CD18)-dependent manner. Immunol 1990; 71: 258-265.

218. Wang JM, Rambaldi A, Biondi A, Chen ZG, Sanderson CJ, Mantovani A. Recombinant human interleukin-5 is a selective eosinophil chemoattractant. Eur J Immunol 1989; 19: 701-705.

219. Oosterhout AJM, Ladenius ARC, Savelkoul HFJ, von Ark I, Delsman KC, Nijkamp FP. Effect of anti-IL-5 and IL-5 on airway hyperreactivity and eosinophils in guinea-pig. Am Rev Respir Dis 1993; 147: 548-552.

220. Lopez AF, Sanderson CJ, Gamble JR, Campbell HR, Young IG, Vadas MA. Recombinant human interleukin5 is a selective activator of human eosinophil function. J Exp Med 1988; 167: 219-224.

221. Weller PF. Cytokine regulation of eosinophil function. Clin Immunol Immunopathol 1992; 62: S55-S59.

222. Kovach JS, Gleich GJ. Eosinophilia and fluid retention in systemic administration of interleukin-2. J Clin Onkol 1986; 4: 815-816.

223. Ettinghausen SE, Moore JG, White DE, Plantanias L, Young NS, Rosenberg SA. Hematologic effects of immunotherapy with lymphokine-activated killer cells and recombinant interleukin-2 in cancer patients. Blood 1987; 69: 1654-1660.

224. Sondel PM, Kohler PC, Hank A, et al. Clinical and immunological effects of recombinant interleukin-2 given by repetitive weekly cycles to patients with cancer. Cancer Res 1988; 48: 2561-2567.

225. Nakamura Y, Ozaki T, Kamei T, et al. Factors that stimulate the proliferation and survival of eosinophils in eosinophilic pleural effusion: relationship to granulocyte/ macrophage colony-stimulating factor, interleukin-5 and interleukin-3. Am J Respir Cell Mol Biol 1993; 8: 605611.

226. Cruikshank WW, Berman JS, Theodore AC, Bernado J, Center DM. Lymphokine activation of T4+ lymphocytes and monocytes. J Immunol 1987; 138: 38173823.

227. Cruikshank WW, Berman JS, Theodore AC, Bernado J, Center DM. Lymphocyte chemoattractant factor (LCF) induces CD4-dependent intracytoplasmic signalling in lymphocytes. J Immunol 1991; 146: 2928-2934.

228. Warringa, RA, Koenderman L, Kok PT, Kreukniet J, Bruijnzeel PL. Modulation and induction of eosinophil chemotaxis by granulocyte/macrophage colony-stimulating factor and interleukin-3. Blood 1991; 77: 2694-2700.

229. Kameyoshi Y, Dörschner A, Mallet AI, Christophers E, Schröder JM. Cytokine RANTES released by thrombin- 
stimulated platelets is a potent attractant for human eosinophils. J Exp Med 1992; 176: 587-592.

230. Rot A, Krieger M, Brunner T, Bischoff SC, Schall TJ, Dahinden CA. RANTES and macrophage inflammatory protein 1a induce the migration and activation of normal human eosinophil granulocytes. J Exp Med 1992; 176: 1489-1495.

231. Schall TJ. Biology of the RANTES/SIS cytokine family. Cytokine 1991; 3: 165-183.

232. Warner JA, Kroegel C. Pulmonary immune cells in health and disease. Mast cells and basophils. Eur Respir $J$ 1994; (in press).

233. Galli SJ. New concepts about the mast cell. N Engl J Med 1993; 328: 257-265.

234. O'Donnell MC, Ackerman SJ, Gleich GJ, Thomas LL. Activation of basophil and mast cell histamine release by eosinophil granular major basic protein. J Exp Med 1983; 157: 1981-1987.

235. Yoshimura K, Uchida K, Sato K, Oya H. Ultrastructural evidence for eosinophil-mediated destruction of Angiostrongylus cantonensis transferred into pulmonary artery of nonpermissive hosts. Parasite Immunol 1984; 6: 105-118.

236. Young JD, Peterson CG, Venge P, Cohn ZA. Mechanism of membrane damage mediated by human eosinophil cationic protein. Nature 1986; 321: 613-616.

237. Young M, Nuss R, Benrubi G. Stromal and peripheral eosinophilia in cervical carcinoma. Eur J Gynaecol Oncol 1985; 6: 94-97.

238. Tobin MC, Karns BK, Abselmino LM, Thomas LL. Potentiation of human basophil histamine release by protamine: a new role for polycation recognition site. Mol Immunol 1986; 23: 245-253.

239. Archer GT, Jackas M. Disruption of mast cells by a component of eosinophil granules. Nature 1965; 205: 599-600.

240. Zheutlin LM, Ackerman SJ, Gleich GJ, Thomas LL. Stimulation of basophil and rat mast cell histamine release by eosinophil granule-derived cationic proteins. J Immunol 1984; 133: 2180-2185

241. Chi EY, Henderson WR. Ultrastructure of mast cell degranulation induced by eosinophil peroxidase: use of diaminobenzidine cytochemistry by scanning electron microscopy. J Histochem Cytochem 1984; 32: 337-341.

242. Henderson WR, Jong EC, Klebanoff SJ. Binding of eosinophil peroxidase to mast cell granules with retention of peroxidase activity. J Immunol 1980; 124: 1384-1388.

243. Henderson WR, Chi EY, Jong EC, Klebanoff SJ. Mast cell-mediated tumor-cell cytotoxicity: role of the peroxidase system. J Exp Med 1981; 153: 520-533.

244. Henderson WR, Kaliner M. Mast cell granule peroxidase: localization, secretion and SRS-A inactivation. J Immunol 1979; 122: 1322-1328.

245. Henderson WR, Chi EY, Klebanoff SJ. Eosinophil peroxidase-induced mast cell secretion. J Exp Med 1980; 152: $265-279$.

246. Hayakawa T, Suzuki K, Suzuki S, Andrews P, Babior BM. A possible role for protein phosphorylation in the activation of the respiratory burst in human neutrophils: evidence from studies with cells from patients with granulomatous disease. J Biol Chem 1986; 261: 91099115.

247. Henderson WR, Chi EY, Jong EC, Klebanoff SJ. Mast cell-mediated toxicity to schistosomula of Schistosoma mansoni: potentiation by exogenous peroxidase. $J$ Immunol 1986; 137: 2695-2699.

248. Butterfield JH, Weiler D, Peterson EA, Gleich GJ, Leiferman KM. Sequestration of eosinophil major basic protein in human mast cells. Lab Invest 1990; 62: 77-86.

249. Dvorak AM, Klebanoff SJ, Henderson WR, Monahan RA, Pyne K, Galli SJ. Vesicular uptake of eosinophil peroxidase by guinea-pig basophils and cloned mouse mast cells and granule-containing lymphoid cells. Am J Pathol 1985; 118: 425-438.

250. Dvorak AM, Ishizaka T, Galli SJ. Ultrastructure of human basophil developing in vitro: Evidence for the aquisition of peroxidase by basophils and for different effects of human and murine growth factors on human basophil and eosinophil maturation. Lab Invest 1985; 53: 57-71.

251. Ackerman SJ, Kephart GM, Habermann TM. Localization of eosinophil granular major basic protein in human basophils. J Exp Med 1983; 158: 946-953.

252. Frigas E, Loegering DA, Gleich GJ. Cytotoxic properties of the eosinophil major basic protein on tracheal epithelium. Lab Invest 1980; 42: 35-43.

253. Motojima S, Frigas E, Loegering DA, Gleich, GJ. Toxicity of eosinophil cationic proteins for guinea-pig tracheal epithelium in vitro. Am Rev Respir Dis 1989; 139: 801805.

254. Nakajima H, Loegering DA, Gleich GJ. Cytotoxicity of eosinophil granule proteins for tumor cells. FASEB $J$ 1988; 2: A811.

255. Tonnel AB, Gosset P, Joseph M, Fournier E, Capron A. Stimulation of alveolar macrophages in asthmatic patients after oral provocation test. Lancet 1993; i: 1406-1408.

256. Calhoun WJ, Reed HE, Moest DR, Stevens CA. Enhanced superoxide production by alveolar macrophages and airspace cells, airway inflammation, and alveolar macrophage density changes after segmental allergen bronchoprovocation in allergic subjects. Am Rev Respir Dis 1992; 145: 317-325.

257. Sibille Y, Marchandise F-X. Pulmonary immune and inflammatory cells in health and disease. Polymorphonuclear neutrophils. Eur Respir J 1993; 6: 1529-1543.

258. Lee TH. Cellular activation and releasability in asthma and in chronic obstructive pulmonary disease. Am Rev Respir Dis 1991; 143: 1162-1164.

259. Jong EC, Chi EY, Klebanoff SJ. Human neutrophilmediated killing of shistosomula of Schistosoma mansoni: augmentation by schistosomal binding of eosinophil peroxidase. Am J Trop Med Hyg 1984; 33: 104-115.

260. Ramsey PG, Martin T, Chi E, Klebanoff SJ. Arming of mononuclear phagocytes by eosinophil peroxidase bound to Staphylococcus aureus. J Immunol 1982; 128: 415-420.

261. Locksey RM, Wilson CB, Klebanoff SJ. Role for endogeneous and acquired peroxidase in the toxoplasmacidal activity of murine and human mononuclear phagocytes. $J$ Clin Invest 1982; 69: 1099-1111.

262. Nogueira NM, Klebanoff SJ, Cohn ZA. T. cruzi: sensitization to macrophage killing by eosinophil peroxidase. J Immunol 1982; 128: 1705-1708.

263. Nathan CF, Klebanoff SJ. Augmentation of spontaneous macrophage-mediated cytolysis by eosinophil peroxidase. J Exp Med 1982; 155: 1291-1308.

264. Moy JN, Gleich GJ, Thomas LL. Noncytotoxic activation of neutrophils by eosinophil granule major basic protein. Effect on superoxide anion generation and lysosomal enzyme release. J Immunol 1990; 145: 2626-2632.

265. Janin A, Torpier G, Courtin P, et al. Segregation of eosinophil proteins in alveolar macrophage compartment in chronic eosinophilic pneumonia. Thorax 1993; 48: $57-62$.

266. Lamas AM, Marcotte GV, Schleimer RP. Human endothelial cells prolong eosinophil survival. Regulation 
by cytokines and glucocorticoids. J Immunol 1989; 142: 3978-3984.

267. Lamas AM, Leon OG, Schleimer RP. Glucosteroids inhibit eosinophil responses to granulocyte/macrophage colony-stimulating factor. J Immunol 1991; 147: 254-259.

268. Rothenberg ME, Owen WF, Silberstein DS, Soberman RF, Austen KF. Eosinophils cocultured with endothelial cells have increased survival and functional properties. Science 1987; 237: 645-647.

269. Bussolino F, Breviaro F, Tetta C, Aglietta M, Mantovani A, Dejana E. Interleukin-1 stimulates platelet-activating factor production in cultured human endothelial cells. $J$ Clin Invest 1986; 77: 2027-2033.

270. Holtzman MJ, Ferdman B, Bohrer A, Turk J. Synthesis of 1-O-hexadecyl molecular species of platelet-activating factor by airway epithelial and vascular endothelial cells. Biochem Biophys Res Commun 1991; 177: 357-364.

271. Rossi V, Breviario F, Ghezzi P, Dejana E, Mantovani A. Prostacyclin synthesis induced in vascular cells by interleukin-1. Science 1985; 229: 174-176.

272. Resnick MB, Weller PF. Mechanism of eosinophil recruitment. Am J Respir Cell Mol Biol 1993; 8: 349-355.

273. Montavani A, Dejana E. Cytokines as communication signals between leukocytes and endothelial cells. Immunol Today 1989; 10: 370-375.

274. Springer TA. Adhesion receptors of the immune system. Nature 1990; 346: 425-434.

275. Dobrina A, Menegazzi R, Carlos TM, et al. Mechanisms of eosinophil adherence to cultured vascular endothelial cells. Eosinophils bind to the cytokine-induced endothelial ligand vascular cell adhesion molecule-1 via the very late activation antigen-4 integrin receptor. J Clin Invest 1991; 88: 20-26.

276. Bochner BS, Luscinskas FW, Gimbrone MA, et al. Adhesion of human basophils, eosinophils and neutrophils to interleukin-1-activated human vascular endothelial cells: contribution of endothelial cell adhesion molecules. J Exp Med 1991; 173: 1553-1556.

277. Weller PF, Rand TH, Goelz SE, Chi-Rosso G, Lobb RJ. Human eosinophil adherence to vascular endothelium mediated by binding to VCAM-1 and ELAM-1. Proc Natl Acad Sci USA 1991; 88: 7430-7433.

278. Kyan-Aung U, Haskard DO, Poston RN, Thornhill MH, Lee TH. Endothelial leukocyte adhesion molecule-1 and intercellular adhesion molecule-1 mediate the adhesion of eosinophils to endothelial cells in vitro and are expressed by endothelium in allergic cutaneous inflammation in vivo. J Immunol 1991; 146: 521-528.

279. Anderson DC, Schmalsteig FC, Finegold MJ, et al. The severe and moderate phenotypes of heritable Mac-1, LFA1, p150.95 deficiency: their quantitative definition and relation to leukocyte dysfunction and clinical features. $J$ Infect Dis 1985; 152: 668-673.

280. Smith JB, Kunjummen RD, Kishimoto TK, Anderson DC. Expression and regulation of L-selectin on eosinophils from human adults and neonates. Pediatr Res 1992; 32: 465-471.

281. Gundel RH, Letts LG, Gleich GJ. Human eosinophil major basic protein induces airway constriction and airway hyperresponsiveness in primates. J Clin Invest 1991; 87: 1470-1473.

282. Walsh GM, Mermod JJ, Hartnell A, Kay AB, Wardlaw AJ. Human eosinophil, but not neutrophil, adherence to IL-1-stimulated human umbilical vascular endothelial cells is alpha-4 beta-1 (very late antigen-4) dependent. J Immunol 1991; 146: 3419-3423.

283. Elices MJ, Osborn L, Takada Y, et al. VCAM-1 on activated endothelium interacts with the leukocyte integrin VLA-4 at a site distinct from the VLA-4/fibronectin binding site. Cell 1990; 60: 577-584.

284. Masenovsky B, Urdal D, Gallatin WM. IL-4 interacts synergistically with IL-1 $\beta$ to promote lymphocyte adhesion to microvasculature endothelium by induction of vascular cell adhesion molecule-1. J Immunol 1990; 145: 2886-2895.

285. Thornhill MH, Wellicome SM, Mahiouz DL, Lachbury JSS, Kyan-Aung U, Haskard DO. Tumor necrosis factor combines with IL-4 or INF- $\gamma$ to selectively enhance endothelial cell adhesion molecule-1-dependent and independent binding mechanisms. J Immunol 1991; 146: 592-598.

286. Schleimer RP, Bochner BS. Endothelial leukocyte adhesion molecule-1 and intercellular adhesion molecule1 mediate the adhesion of eosinophils to endothelial cells in vitro and are expressed by endothelium in allergic cutaneous inflammation in vivo. J Immunol 1991; 147: 380-381.

287. Tepper RI, Levinson DA, Stanger BZ, Campos-Torres J, Abbas AK, Leder P. IL-4 induces allergic-like inflammatory disease and alters T-cell development in transgeneic mice. Cell 1990; 62: 457-467.

288. Tepper RI, Coffman RL, Leder P. An eosinophil-dependent mechanism for the antitumor effect of interleukin-4. Science 1992; 257: 548-551.

289. Hansel TT, Walker C. The migration of eosinophils into the sputum of asthmatics: the role of adhesion molecules. Clin Exp Allergy 1992; 22: 345-356.

290. Ohashi Y, Motojima S, Fukuda T, Makino S. Airway hyperresponsiveness, increased intracellular spaces and bronchial epithelium, and increased infiltration of eosinophils and lymphocytes in bronchial asthma. Am Rev Respir Dis 1992; 145: 1469-1476.

291. Marini M, Vittori E, Hollemberg J, Mattoli S. Expression of the potent inflammatory cytokines, granulocyte/ macrophage colony-stimulating factor, interleukin-6, and interleukin-8, in bronchial epithelial cells of patients with asthma. J Allergy Clin Immunol 1992; 89: 1001-1009.

292. Cox G, Ohtoshi T, Vancheri C, Denberg JA, Dolovich J, Gauldie J, Jordana M. Promotion of eosinophil survival by human bronchial epithelial cells and its modulation by steroids. Am Respir Cell Mol Biol 1991; 4: 525-531.

293. Marini M, Soloperto M, Mezzetti MM, Fasoli A, Mattoli S. Interleukin-1 binds to specific receptors on human bronchial epithelial cells and upregulates granulocyte/ macrophage colony-stimulating factor synthesis and release. Am J Respir Cell Mol Biol 1991; 4: 519-524.

294. Holtzman MJ, Hansborough JR, Rosen GD, Turk J. Uptake, release and novel species-dependent oxygenation of arachidonic acid in human and animal airway epithelial cells. Biochem Biophys Acta 1988; 963: 401-413.

295. Hunter JA, Finkbeiner WE, Nadel JA, Goetzl EJ, Holtzman MJ. Predominant generation of 15-lipoxygenase metabolites of arachidonic acid by epithelial cells from human trachea. Proc Natl Acad Sci USA 1985; 82: 4633-4637.

296. Sousa, AR, Poston RN, Lane SJ, Nakhosteen JA, Lee TH. Detection of GM-CSF in asthmatic bronchial epithelium and decrease by inhaled corticosteroids. Am Rev Respir Dis 1993; 147: 1557-1561.

297. Montefort S, Baker J, Roche WR, Holgate ST. The distribution of adhesive mechanisms in the normal bronchial epithelium. Eur Respir J 1993; 6: 1257-1263.

298. Montefort S, Roche WR, Howarth PH, et al. Intercellular adhesion molecule-1 (ICAM-1) and ELAM-1 expression in the bronchial mucosa of normal and asthmatic subjects. Eur Respir J 1992; 5: 815-832. 
299. Capron A, Ameisen JC, Joseph M, Aurriault C, Tonnel $\mathrm{AB}$, Caen J. New functions for platelets and their pathophysiological implications. Arch Allergy Appl Immunol 1985; 77: 107-114.

300. Page CP, Paul W, Basran CS, Morley J. Platelet activation in asthma. In: Stein E, ed. Bronchial Asthma, Mechanisms and Therapeutics. Boston, Little \& Brown, 1985; pp. 266-269.

301. Pinkard RN, Halonen M, Palmer JD, Butler C, Shaw JO, Henson PM. Intravascular aggregation and pulmonary sequestration of platelets during IgE-induced systemic anaphylaxis in the rabbit: abrogation of lethal anaphylactic shock by platelet depletion. J Immunol 1977; 119: 2185-2193.

302. Mazzoni L, Morley J, Page CP, Sanjar S. Induction of airway hyperresponsiveness induced by platelet-activating factor in the guinea-pig. J Physiol 1985; 369: 107.

303. Averill FJ, Hubbard WC, Proud D, Gleich D, Liu MC. Platelet activation in the lung after antigen challenge in a model of allergic asthma. Am Rev Respir Dis 1992; 145: 571-576.

304. Knauer AA, Lichtenstein LM, Adkinson FN, Fish JE. Platelet activation during antigen-induced airway reaction in asthmatic subjects. N Engl J Med 1981; 204: 1404-1406.

305. Rohrbach MS, Wheatley CL, Slifman NR, Gleich GJ. Activation of platelets by eosinophil granule proteins. $J$ Exp Med 1990; 72: 1271-1274.

306. Laitinen LA, Heino M, Laitinen A, Kava, Haahtela T. Damage of airway epithelium and bronchial reactivity in patients with asthma. Am Rev Respir Dis 1985; 131: 599-606.

307. Jeffrey PK, Nelson FC, Wardlaw AJ, Kay AB, Collins JV. Quantitative analysis of bronchial biopsies in asthma. Am Rev Respir Dis 1987; 135: A316.

308. Laitinen L, Laitinen A, Neino M, Haahtela T. Eosinophilic airway inflammation during exacerbation of asthma and its treatment with inhaled corticosteroids. Am Rev Respir Dis 1991; 143: 423-427.

309. Kornfeld H, Berman JS, Beer DJ, Center DM. Induction of human T-lymphocyte motility by interleukin-2. $J$ Immunol 1985; 134: 3887-3890.

310. Robinson DA, Hamid Q, Ying S, et al. Predominant
Th2-like bronchoalveolar T-lymphocyte population in atopic asthma. N Engl J Med 1992; 326: 298-304.

311. Walker C, Bode E, Boer L, Nansel TT, Blaser K, Virchow JC Jr. Allergic and nonallergic asthmatics have a distinct pattern of T-cell activation and cytokine production in peripheral blood and BAL. Am Rev Respir Dis 1992; (in press).

312. Vancheri C, Gauldie J, Bienenstock J, et al. Human lung fibroblast-derived granulocyte/macrophage colonystimulating factor (GM-CSF) mediates eosinophil survival in vitro. Am J Respir Cell Mol Biol 1989; 1: 289-295.

313. Shock A, Rabe KF, Dent G, et al. Eosinophils adhere to and release mitogens for fibroblasts. Am Rev Respir Dis 1991; 143: 528.

314. Pincus SH, Ramesh KS, Wyler DJ. Eosinophils stimulate fibroblast DNA synthesis. Blood 1987; 70: 572-574.

315. Lawrence MB, Springer TA. Leukocytes role on a selectin at physiologic flow rates: distinction from prerequisite for adhesion through integrins. Cell 1991; 65: 859-873.

316. Rosen H. The LEC-CAMs: an emerging family of cellcell adhesion receptors based upon carbohydrate recognition. Am J Respir Cell Mol Biol 1990; 3: 397-402.

317. Lasky LA, Springer MS, Dowbenko D, et al. An endothelial ligand for L-selectin is novel mucin-like molecule. Cell 1992; 69: 927-938.

318. Kroegel C, Walker C, Häfner D, et al. Potential role of cytokines for eosinophil heterogeneity and function in asthma. Evidence to different functional states of BAL eosinophils in allergic airway inflammation following segmental antigen challenge. J Immunol 1994; (in press).

319. Gimbrone MA, Obin MS, Brock AF, et al. Endothelial IL-8: a novel inhibitor of leukocyte endothelial interaction. Science 1989; 246: 1601-1603.

320. Silberstein DS, Austen HF, Owen WF. Hemopoietins for eosinophils. Glycoprotein hormones that regulate the development of inflammation in eosinophil-associated disease. Hematol Oncol Clin North Am 1989; 3: 511-533.

321. Nathan C, Sporn M. Cytokines in context. J Cell Biol 1991; 113: 981-986.

322. Berman JS, Weller PF. Airway eosinophils and lymphocytes in asthma. Birds of a feather? Am Rev Respir Dis 1992; 1455: 1246-1248. 